\title{
Interaction and localization studies of enteropathogenic Escherichia coli type IV bundle-forming pilus outer membrane components
}

\author{
Anu Daniel,† Aparna Singh, Lynette J. Crowther, Paula J. Fernandes, \\ Wiebke Schreiber and Michael S. Donnenberg
}

Correspondence

Michael S. Donnenberg

mdonnenb@umaryland.edu

Received 20 January 2006

Revised 1 May 2006

Accepted 8 May 2006

\author{
Division of Infectious Diseases, Department of Medicine, University of Maryland School of \\ Medicine, 20 Penn Street, Baltimore, MD 21201, USA
}

\begin{abstract}
Typical enteropathogenic Escherichia coli strains express an established virulence factor belonging to the type IV pili family, called the bundle-forming pilus (BFP). BFP are present on the cell surface as bundled filamentous appendages, and are assembled and retracted by proteins encoded by the bfp operon. These proteins assemble to form a molecular machine. The BFP machine may be conceptually divided into three components: the cytoplasmic membrane (CM) subassembly, which is composed of CM proteins and cytoplasmic nucleotide-binding proteins; the outer membrane (OM) subassembly and the pilus itself. The authors have previously characterized the CM subassembly and the pilus. In this study, a more complete characterization of the OM subassembly was carried out using a combination of biochemical, biophysical and genetic approaches. It is reported that targeting of $B f p G$ to the $O M$ was influenced by the secretin BfpB. BfpG and BfpU interacted with the amino terminus of BfpB. BfpU had a complex cellular distribution pattern and, along with $\mathrm{BfpB}$ and $\mathrm{BfpG}$, was part of the OM subassembly.
\end{abstract}

\section{INTRODUCTION}

It is becoming increasingly clear that many cellular processes are carried out, not by individual proteins functioning in isolation, but by macromolecular complexes and intricate protein networks (Alberts, 1998; Phizicky et al., 2003). Structural and biochemical characterizations of such macromolecular assemblies are being undertaken to obtain a better understanding of the cellular processes they control. These considerations also apply to proteins and processes involved in bacterial pathogenesis. Type IV pili (Tfp) of Gram-negative bacteria are assembled by one such multicomponent molecular machine (Anantha et al., 2000; Ramer et al., 2002). Tfp are filamentous surface appendages that are expressed by many pathogenic bacteria, including Pseudomonas aeruginosa, Vibrio cholerae, Neisseria gonorrhoeae, Neisseria meningitidis, Salmonella enterica serovar Typhi, Legionella pneumophila, and enteropathogenic (EPEC) and enterotoxigenic Escherichia coli (Hobbs \& Mattick, 1993; Strom \& Lory, 1993; Zhang et al., 2000; Stone \& Abu Kwaik,

†Present address: Laboratory of Bacterial Pathogenesis and Immunology, The Rockefeller University, 1230 York Avenue, NY 10021, USA.

Abbreviations: AHT, anhydrotetracycline; Al, autoaggregation index; BFP, bundle-forming pilus; CM, cytoplasmic membrane; DSP, dithiobis[succinimidyl] propionate; EPEC, enteropathogenic Escherichia coli; $\alpha$-Gal, $\alpha$-galactosidase; His 6 , hexahistidine; ITC, isothermal titration calorimetry; MBP, maltose-binding protein; $\beta$-ME, $\beta$-mercaptoethanol; OM, outer membrane; Tfp, type IV pili.
1998; Taniguchi et al., 1995; Girón et al., 1991). Tfp play a role in diverse processes, such as cellular adhesion (Lee et al., 1994; Rudel et al., 1995), colonization (Herrington et al., 1988; Tacket et al., 1998), twitching motility (Bradley, 1980; Henrichsen, 1983; Merz et al., 2000; Wall \& Kaiser, 1999), biofilm formation (O’Toole \& Kolter, 1998), horizontal gene transfer (Seifert et al., 1988; Yoshida et al., 1999) and virulence (Tacket et al., 1998; Herrington et al., 1988; Bieber et al., 1998). Proteins of the Tfp biogenesis machine share extensive sequence similarity to proteins of type II secretion systems (T2SSs) and DNA uptake systems, and have orthologues among the proteins required for the assembly of filamentous phages and archaeal flagellae, suggesting that these systems are structurally and mechanistically similar and share an ancient evolutionary link (Chen \& Dubnau, 2003; Russel, 1998; Craig et al., 2004; Sandkvist, 2001; Peabody et al., 2003).

Tfp are homopolymeric structures composed of the pilin structural protein (Craig et al., 2004). Mature pilin is generated from the pre-pilin precursor, which contains an unusual short positively charged leader peptide, by a pre-pilin peptidase, which also $N$-methylates the nascent amino terminus (Strom et al., 1993). A number of conserved accessory genes are required for Tfp biogenesis, including those encoding the pre-pilin peptidase, a polytopic cytoplasmic membrane (CM) protein, pre-pilin-like proteins, nucleotide-binding proteins, and an outer membrane (OM) secretin. Mutational analyses have revealed that these 
proteins are required for functional Tfp biogenesis but not for pre-pilin expression or processing (Alm \& Mattick, 1997; Anantha et al., 2000; Ramer et al., 2002). Tfp can be divided into two groups, A and B, based on differences in the signal peptide, cleavage site and genomic organization (Craig et al., 2004). Although the biogenesis of Tfp is not well understood, conditional double-knockout mutants of N. gonorrhoeae have revealed three steps in Tfp biogenesis: pilin processing, pilus formation and pilus extrusion (Wolfgang et al., 1998, 2000). Since the second and third steps appear to be coupled, it is likely that the proteins involved in Tfp biogenesis interact to form a single molecular machine (Hwang et al., 2003; Crowther et al., 2004).

EPEC strains are a leading cause of severe infantile diarrhoea in developing countries (Donnenberg \& Kaper, 1992). Typical EPEC strains contain an EPEC adherence factor (EAF) plasmid that is associated with the ability of the bacteria to adhere to the surface of epithelial cells in a distinctive pattern of 3D clusters called localized adherence (Cravioto et al., 1979; Scaletsky et al., 1984; Baldini et al., 1983). In liquid culture, the cells form dynamic bacterial aggregates; phenomena called autoaggregation and disaggregation (Vuopio-Varkila \& Schoolnik, 1991; Bieber et al., 1998). Both these phenotypes are dependent on a Tfp called the bundle-forming pilus (BFP), an established EPEC virulence factor (Bieber et al., 1998). The EAF plasmid contains the $b f p$ operon, which encodes proteins that comprise and assemble the BFP. The $b f p$ operon consists of 14 genes designated $b f p A$ to $b f p L, b f p P$ and $b f p U$. This operon is sufficient for the biogenesis and function of BFP when cloned and expressed in a laboratory strain of $E$. coli (Stone et al., 1996). The first gene of the $b f p$ operon is $b f p A$, which encodes pre-bundlin, the pre-pilin (Donnenberg et al., 1992; Sohel et al., 1993). Processing of pre-bundlin to bundlin is dependent on two enzymes: pre-pilin peptidase, a $b f p P$ gene product that cleaves the cytoplasmic signal sequence (Zhang et al., 1994), and DsbA, which catalyses formation of a disulfide linkage in the periplasmic carboxyl-terminus of bundlin (Zhang \& Donnenberg, 1996). A kinetic analysis of bundlin maturation has revealed that during processing, pre-bundlin exists as a $\mathrm{CM}$ protein accessible to both enzymes simultaneously (Donnenberg et al., 1997). BfpP also processes the pre-pilin-like proteins encoded by the $b f p I, b f p J$ and $b f p K$ genes (Ramer et al., 2002). BfpB, the product of the $b f p B$ gene, belongs to the secretin family of proteins. BfpB is a lipoprotein and forms multimers that may have pore-forming activity (Ramer et al., 1996). BfpG is encoded by the second gene of the $b f p$ operon and has no homologues. Immunoprecipitation and crosslinking studies have shown that BfpG interacts with BfpB (Schmidt et al., 2001; Hwang et al., 2003). BfpU is a small protein encoded by the $b f p U$ gene, which localizes to both the cytoplasm and periplasm. Its function is not yet understood and it has no known homologues (Schreiber et al., 2002). The $b f p D$ gene encodes a hexameric cytoplasmic ATPase, while the $b f p F$ gene encodes a putative cytoplasmic nucleotide-binding protein involved in pilus retraction
(Anantha et al., 1998; Bieber et al., 1998). BfpE is a polytopic CM protein (Blank \& Donnenberg, 2001) and BfpC is a bitopic CM protein (Crowther et al., 2004). In the presence of the cytoplasmic amino terminus of $\mathrm{BfpC}$ and a peptide derived from the cytoplasmic amino terminus of BfpE, $\mathrm{BfpD}$ is a powerful ATPase (Crowther et al., 2005). A single hexamer of $\mathrm{BfpD}$ is capable of hydrolysing 455 molecules of ATP per second.

Our group recently provided evidence for a CM subassembly of the BFP biogenesis machine (Crowther et al., 2004). This subassembly contains the bitopic CM protein BfpC, polytopic $\mathrm{CM}$ protein $\mathrm{BfpE}$, as well as the cytoplasmic ATPase BfpD and the putative ATPase BfpF. The amino termini of $\mathrm{BfpC}$ and $\mathrm{BfpE}$ interact with each other and with the BfpD ATPase. These interactions induce conformational changes in each protein, and are required for bacterial autoaggregation and hence for pilus biogenesis. In contrast, $\mathrm{BfpF}$ interacts only with the small (25 aa) cytoplasmic loop of $\mathrm{BfpE}$, and this interaction is required for disaggregation and hence pilus retraction.

Hwang et al. (2003) have demonstrated that the OM protein $\mathrm{BfpB}$ can be cross-linked with nine of the 13 other BFP proteins. Only $\mathrm{BfpH}$, which may not be expressed, the prepilin peptidase $\mathrm{BfpP}$, and the pre-pilin-like proteins BfpJ and $\mathrm{BfpK}$, could not be detected in the cross-linked complexes. Since the BfpB cross-linked complex contained both CM components, such as $\mathrm{BfpC}$ and $\mathrm{BfpE}$, and $\mathrm{OM}$ components $\mathrm{BfpB}$ and $\mathrm{BfpG}$, an oligomeric complex spanning the periplasmic space was proposed. Schmidt et al. (2001) have demonstrated that $\mathrm{BfpB}$ and $\mathrm{BfpG}$ are present in the $\mathrm{OM}$, and have provided evidence that $B f p G$ is required for formation and/or stability of the $\mathrm{BfpB}$ multimer. Based on these observations, it has been proposed that $\mathrm{BfpB}$ and $\mathrm{BfpG}$ form the OM component of the BFP machine. As a conceptual framework to facilitate experimentation, we envision the BFP machine to consist of a CM subassembly and an OM subassembly. Since BfpU is present in the periplasm in addition to the cytoplasm (Schreiber et al., 2002), our hypothesis states that $\mathrm{BfpU}$ interacts with $\mathrm{BfpB}$ and $\mathrm{BfpG}$ as part of the OM subassembly. As a corollary to this hypothesis, we predicted that the absence of some proteins of the OM subassembly would alter or influence the targeting of the interacting partners within the cell. In this study, we investigated interactions among $\mathrm{BfpB}, \mathrm{BfpG}$ and $\mathrm{BfpU}$ in order to characterize the OM subassembly of the BFP biogenesis machine.

\section{METHODS}

E. coli strains and growth conditions. The strains and plasmids used in this study are listed in Table 1 . SlyD is a histidine-rich peptidyl-prolyl trans-isomerase that can contaminate proteins purified by metal chelation chromatography (Hottenrott et al., 1997). To construct a $s l y D$ mutant to facilitate protein purification, we used a one-step lambda Red recombinase-facilitated mutagenesis protocol to delete the $s l y D$ gene of E. coli strain BW25113, replacing it with the sequences of a chloramphenicol-resistance gene (Datsenko \& 
Table 1. Strains and plasmids used in this study

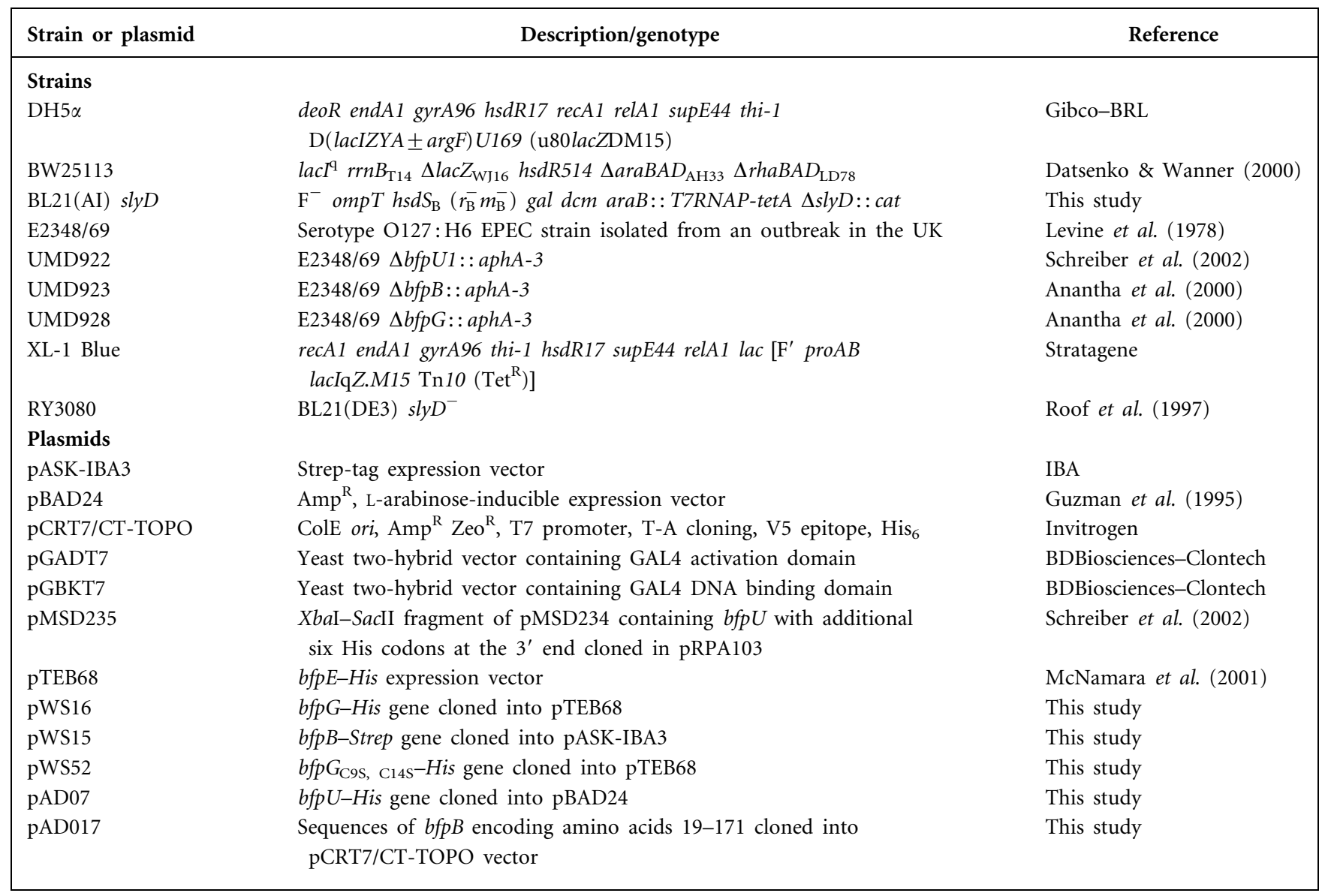

Wanner, 2000). Primers Donne-733 and Donne-734 used for this procedure are listed in Table 2 . We then used bacteriophage P1 to transduce the mutation to strain BL21(AI), which contains the T7 polymerase under the control of the $P_{\mathrm{BAD}}$ promoter (Invitrogen). The mutation was confirmed by PCR and sequencing.

Bacterial strains were cultured in Luria-Bertani broth at $37^{\circ} \mathrm{C}$. BFP was expressed as previously described (Schreiber et al., 2002). Antibiotics were added at the following concentrations to select for or maintain plasmids: ampicillin, $200 \mu \mathrm{g} \mathrm{ml}^{-1}$; chloramphenicol, $20 \mu \mathrm{g} \mathrm{ml}^{-1}$; kanamycin, $50 \mu \mathrm{g} \mathrm{ml}^{-1}$.

Autoaggregation assays. The autoaggregation phenotype, which requires expression of BFP (Anantha et al., 2000), was tested as previously described (Crowther et al., 2004). The autoaggregation index (AI), which measures the percentage increase in optical density following disruption of aggregates after vortexing as a function of time, was also determined as described by Anantha et al. (1998).

Chemical cross-linking and affinity purification of complexes. Overnight cultures of E. coli UMD922(pMSD235) expressing BfpU tagged at its carboxyl terminus with hexahistidine $\left(\mathrm{His}_{6}\right)$ (BfpU-His) in a bfpU mutant background (Schreiber et al., 2002); strain UMD928(pWS16) expressing His $_{6}$-tagged BfpG (BfpG-His) in a $b f p G$ mutant background; and strain UMD923(pWS15) expressing Strep-tagged BfpB (BfpB-Strep) in a $b f p B$ mutant background, were grown under BFP-inducing conditions. For strain UMD928(pWS16), IPTG (1 mM final concentration) was added to the cultures to induce BfpG expression, and for strain UMD923(pWS15), anhydrotetracycline (AHT) was added $\left(20 \mu \mathrm{g} 100 \mathrm{ml}^{-1}\right.$ final concentration) to induce $\mathrm{BfpB}$ expression. Cells were harvested, washed and resuspended in PBS to $\mathrm{OD}_{600} 1 \cdot 0$. The membrane-permeable, homobifunctional thiol-cleavable, chemical cross-linker dithiobis[succinimidyl] propionate (DSP) (Pierce) was added to a final concentration of $0.125 \mathrm{mM}$, and incubated at room temperature for $30 \mathrm{~min}$. The reaction was quenched with 0.25 vol. $1 \mathrm{M}$ Tris $/ \mathrm{HCl}$ ( $\mathrm{pH} \mathrm{7.4)}$ for $15 \mathrm{~min}$ at room temperature. For strains UMD928(pWS16) and UMD922(pMSD235), cells were resuspended in lysis buffer $\left(50 \mathrm{mM} \mathrm{NaH} \mathrm{PO}_{4}, 300 \mathrm{mM} \mathrm{NaCl}, 10 \mathrm{mM}\right.$ imidazole, pH 8.0) and lysed in a French press at 20000 p.s.i. $(\sim 138000 \mathrm{kPa})$. The lysates were cleared by centrifugation and the cross-linked complexes were purified by nickel-nitrilotriacetic acid (Ni-NTA) (Qiagen) affinity chromatography according to the manufacturer's instructions. For strain UMD923(pWS15), cells were resuspended in buffer A (100 mM Tris/HCl, $100 \mathrm{mM} \mathrm{NaCl}, 1 \mathrm{mM}$ EDTA, pH 7·0) and lysed in a French press at 20000 p.s.i. $(\sim 138000 \mathrm{kPa})$. The lysates were centrifuged at $6000 \mathrm{~g}$ to remove cell debris, and membranes were pelleted at $100000 \mathrm{~g}$. The membrane preparation was solubilized in buffer A+2\% SDS for $10 \mathrm{~min}$, and unsolubilized material was removed by centrifugation at $100000 \mathrm{~g}$. The SDS concentration in the supernatant was decreased to $<0 \cdot 1 \%$ with buffer A. Complexes were purified using affinity chromatography by mixing with a slurry of Strep-Tactin Sepharose (IBA) for $20 \mathrm{~min}$ at room temperature. The slurry was loaded on a column and washed twice with buffer $\mathrm{A}$, followed by elution with buffer D (buffer A+2.5 mM desthiobiotin). Eluted proteins were dialysed against buffer A to remove desthiobiotin and concentrated by ultrafiltration (Centricon 
Table 2. Primers used in this study

\begin{tabular}{|c|c|c|}
\hline Name & Sequence & Purpose \\
\hline Donne-402 & 5'-CAT GCC ATG GTG AGG ACA GTA ATC CTT TTT T-3' & Forward primer for BfpG purification \\
\hline Donne-405 & 5'-CGG GAT CCT CCT TCG GGT GAT TGT GTA AC-3' & Reverse primer for BfpG purification \\
\hline Donne-419 & $\begin{array}{l}\text { 5'-CAA GAT GGT CTC AGC GCT TTC GCC ATA AGC CTT GAG } \\
\text { AT-3' }\end{array}$ & Reverse primer for $\mathrm{BfpB}$ purification \\
\hline Donne-420 & 5'-AAG GAT GGT CTC AAA TGA AAC TTG GCA GGT ATT C-3' & Forward primer for BfpB purification \\
\hline Donne-503 & $\begin{array}{l}\text { 5'-CAT GCC ATG GTG AGG ACA GTA ATC CTT TTT TTTA GTC } \\
\text { TTT TGG TAT CCA GTT T-3' }\end{array}$ & $\begin{array}{l}\text { Forward primer to replace } \mathrm{C} 9 \text { and } \mathrm{C} 14 \\
\text { of pre-BfpG with } \mathrm{S}\end{array}$ \\
\hline Donne-733 & $\begin{array}{l}\text { 5'-ATC GCG TCG CAG GCT GAA GAA ACG CCA CCG CCA CAT } \\
\text { TAT TGA GGC GTA AAA AAA GCG GGG CAT ATG AAT ATC } \\
\text { CTC CTT AG-3' }\end{array}$ & Reverse primer for $s l y D$ deletion \\
\hline Donne-734 & $\begin{array}{l}\text { 5'-CAC GGC TGC AGA ATT CCG CTA CAA TCT GCG CCA CTA } \\
\text { TTC TTC CCA TGC TCA GGA GAT ATC GTG TAG GCT GGA } \\
\text { GCT GCT TC-3' }\end{array}$ & Forward primer for $s l y D$ deletion \\
\hline Donne-803 & 5'-CGG ATC CCT ATC TCA GAA AAA TTT TCT-3' & $3^{\prime}$ End of $b f p U$ in $\mathrm{pGAD} / \mathrm{T} 7$ and $\mathrm{pGBK} / \mathrm{T} 7$ \\
\hline Donne-824 & 5'-CGG AAT TCG ACT CTA GAA AAG AAG AAA A-3' & $5^{\prime}$ End of $b f p U$ in $\mathrm{pGAD} / \mathrm{T} 7$ and $\mathrm{pGBK} / \mathrm{T} 7$ \\
\hline Donne-874 & $\begin{array}{l}\text { 5'-CAT GCC ATG GCA GAG GTC AAT ACA AGT GTT GAT GTT } \\
\text { TCC GG-3' }\end{array}$ & $5^{\prime}$ End of $b f p U$ in pBAD24 \\
\hline Donne-875 & 5'-CAT GGT CGA CCT AGT GAT GGT GAT GGT GAT G-3' & $3^{\prime}$ End of $b f p U$ in $\mathrm{pBAD} 24$ \\
\hline Donne-896 & $\begin{array}{l}\text { 5'-CATG GAA TTC TCG GGT AAT GGA TTT TAT AAA GAT } \\
\text { AAT CTT G-3' }\end{array}$ & $5^{\prime}$ End of $b f p B$ in pGADT7 and pGBKT7 \\
\hline Donne 897 & 5'-CATG GGA TCC TCA TTC GCC AGA AGC CTT GAG ATC-3' & $3^{\prime}$ End of $b f p B$ in pGADT7 and pGBKT7 \\
\hline Donne-898 & 5'-CATG GAA TTC CAG GAA AGT GCA AAT AAA AAC GAG-3' & $5^{\prime}$ End of $b f p G$ in pGADT7 and pGBKT7 \\
\hline Donne-899 & 5'-CATG GGA TCC TTA TCC TTC GGG TGA TTG TGT AAC-3' & $3^{\prime}$ End of $b f p G$ in pGADT7 and pGBKT7 \\
\hline Donne-918 & $\begin{array}{l}\text { 5'-CATG GAA TTC TCG GGT AAT GGA TTT TAT AAA GAT AAT } \\
\text { CTT G-3' }\end{array}$ & $\begin{array}{l}5^{\prime} \text { End of bfpB55-513 in pGADT7 and } \\
\text { pGBKT7 }\end{array}$ \\
\hline Donne-919 & 5'-CATG GGA TCC AAG TAC AGG TTT GTA GTT TGC CGC-3' & $\begin{array}{l}3^{\prime} \text { End of } b f p B 55-513 \text { in pGADT7 and } \\
\text { pGBKT7 }\end{array}$ \\
\hline Donne-940 & $\begin{array}{l}\text { 5'-CATG GAA TTC GCG CTT TCC ACG TTT CTT GAT AAA GTT } \\
\text { G-3' }\end{array}$ & $\begin{array}{l}5^{\prime} \text { End of bfpB514-1662 in pGADT7 and } \\
\text { pGBKT7 }\end{array}$ \\
\hline Donne-941 & 5'-CATG GGA TCC ATC ATT CGC CAG AAG CCT TGA GAT C-3' & $\begin{array}{l}3^{\prime} \text { End of } b f p B 514-1662 \text { in pGADT7 and } \\
\text { pGBKT7 }\end{array}$ \\
\hline Donne-968 & 5'-C ATG TCG GGT AAT GGA TTT TAT AAA GAT AAT CTT G-3' & $5^{\prime}$ End of $b f p B 55-513$ in $\mathrm{pCRT7/CT-TOPO}$ \\
\hline Donne-969 & 5'-AAG TAC AGG TTT GTA GTT TGC CGC-3' & $3^{\prime}$ End of $b f p B 55-513$ in pCRT7/CT-TOPO \\
\hline
\end{tabular}

PL-10; Millipore). Flow-through and eluates of all complexes were concentrated and analysed by SDS-PAGE electrophoresis in the presence or absence of $\beta$-mercaptoethanol, $(\beta$-ME) or by Western blotting.

Preparation of soluble and insoluble (membrane) fractions. Soluble and insoluble membrane fractions were prepared as previously described by O'Connell et al. (2004). The protein concentrations of the soluble and insoluble fractions were measured with the bicinchoninic acid method (Pierce), and NADH oxidase assays were performed as previously described by Osborn et al. (1972).

Western blotting. Western blotting was performed as described previously (Schreiber et al., 2002). Primary antibodies were used at the following dilutions: monoclonal anti-bundlin ICA4, 1:30000 (Girón et al., 1995); monoclonal anti-BfpU, 1:30000 (Schreiber et al., 2002); anti-maltose-binding protein (MBP) 1:10000 (New England Biolabs); anti-GroEL conjugated to horseradish peroxidase (HRP) 1:80000 (Sigma). A rabbit polyclonal antiserum was raised against purified $\mathrm{BfpC}_{1-164}$ (Crowther et al., 2004) and used at a dilution of $1: 3000$. A rabbit polyclonal antibody was raised against purified BfpG-His, absorbed thrice against an acetone powder of $b f p G$ mutant strain UMD928, and used at a dilution of $1: 10000$. The polyclonal BfpB antiserum was obtained commercially (Research Genetics) from rabbits immunized with a multiple-antigenic peptide (NILHADTSLLKSKNKEH-YKJSSD) representing amino acids 3455 of $\mathrm{BfpB}$, and used at a dilution of $1: 15000$. Secondary goat antimouse IgG or goat anti-rabbit IgG antiserum conjugated to HRP (Amersham Pharmacia Biotech) were used at a dilution of $1: 30000$. Blots were developed by enhanced chemiluminescence using the ECL kit (Amersham Pharmacia Biotech). When necessary, blots were stripped using Stripping Buffer (Pierce), according to the manufacturer's instructions.

Sucrose density gradient fractionation. Membrane fractionation using sucrose flotation density gradient centrifugation was performed as described previously (Anantha et al., 2000). The presence of OmpA as a marker of OM protein fractions was assessed by Ponceau staining as described by Anantha et al. (2000).

Periplasmic fraction preparation. A method employing gentle Triton X-100 detergent treatment to separate periplasmic and cellular fractions of bacteria was used as previously described (Schreiber et al., 2002). 


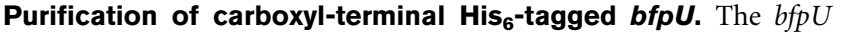
gene, including the codons for a carboxyl-terminal $\mathrm{His}_{6}$ tag, was PCR-amplified from pMSD235 (Schreiber et al., 2002) with primers Donne-874 and Donne-875 (Table 2), cloned into the NcoI-SalI sites of pBAD24 (Guzman et al., 1995), and confirmed by sequencing. The resulting plasmid, named pAD07, was electroporated into DH5 $\alpha$ and BL21(AI) $s l y D$ strains. For overexpression of BfpU-His, strain BL21(AI) $s l y D(\mathrm{pAD} 07)$ was grown in MOPS Minimal Medium to prevent formation of inclusion bodies. Cultures were induced at $\mathrm{OD}_{600} \sim 0.3$ with $1 \mathrm{mM}$ IPTG overnight. Cells were lysed in a French press in lysis buffer. BfpU-His was batch-purified by NiNTA affinity chromatography (Qiagen), further purified with a nickel HiTrap HP column (Amersham Biosciences) according to the manufacturer's instructions, and purity-assessed by SDS-PAGE and silver staining.

Purification of BfpB and BfpG. The $b f p G$ gene was amplified with primers Donne-402 and Donne-405 (Table 2), and the resulting PCR product was cloned in pTEB68 (Table 1) so as to replace the $b f p E$ gene with $b f p G$, creating a gene fusion with the codons for six histidine residues at the $3^{\prime}$ end. The resulting plasmid was designated pWS16. Alternatively, the $b f p G$ gene was amplified with primers Donne-503 and Donne-405 (Table 2) to replace both codons for cysteine 9 and cysteine 14 with serine, and cloned into pTEB68 (Table 1) to create pWS52. BfpG-His was purified either from the complemented $b f p G$ mutant strain UMD928(pWS16) or $E$. coli RY3080(pWS16) by Ni-NTA (Qiagen) affinity chromatography according to the manufacturer's instructions. The purified protein from the complemented $b f p G$ mutant was analysed by silver staining after electrophoresis through an 8-16\% gradient polyacrylamide gel, and transferred to a PVDF membrane for Edman degradation sequencing by the University of Virginia Biomolecular Research Facility.

To purify BfpB, the $b f p B$ gene was amplified using primers Donne- 420 and Donne-419 (Table 2), and cloned into pASK-IBA3 to add a carboxyl-terminal Strep-tag (Table 1). BfpB-Strep was purified from XL-1 Blue(pWS15) by Strep-Tactin Sepharose affinity chromatography, as described for purification of BfpB-cross-linked complexes.

Purification of the $\mathrm{His}_{\mathbf{6}}$-tagged amino-terminal third of bfpB. The fragment of $b f p B$ encoding amino acids serine 19 to glycine 171, referred to hereafter as $\mathrm{BfpB}_{19-171}$, was PCR-amplified with primers Donne-968 and Donne-969 (Table 2), and cloned into pCRT7/CTTOPO (Invitrogen), which adds a carboxyl-terminal $\mathrm{His}_{6}$ tag. The resulting plasmid, named pAD017, was electroporated into the BL21(AI) slyD strain. $\mathrm{BfpB}_{19-171}$ was purified under denaturing conditions by Ni-NTA (Qiagen) affinity chromatography, according to the manufacturer's instructions. $\mathrm{BfpB}_{19-171}$ was refolded by sequentially dialysing against the latter buffer with 3,1 and $0 \mathrm{M}$ urea. The protein was concentrated by ultrafiltration (Centricon PL-10; Millipore).

Yeast two-hybrid analysis. Yeast two-hybrid analysis was done using the Matchmaker GAL4 Two-Hybrid System 3 (Clontech) according to the manufacturer's instructions. Primers designed to amplify sequences of $b f p G$ encoding BfpG lacking its signal sequence, $b f p B$ encoding $\mathrm{BfpB}$ lacking its signal sequence, $\mathrm{BfpB}_{19-171}$ and carboxyl-terminal BfpB (Ala172 to Glu553), referred to hereafter as $\mathrm{BfpB}_{72-553}$, were used to generate fragments subsequently cloned into vectors pGBKT7 and pGADT7 (Table 2).

Microcalorimetry titration studies. Isothermal titration calorimetry (ITC) measurements were carried out at $37^{\circ} \mathrm{C}$ with a VP-ITC MicroCalorimeter (MicroCal). All titrations were performed in $50 \mathrm{mM} \mathrm{NaH} \mathrm{PO}_{4}, 300 \mathrm{mM} \mathrm{NaCl}, \mathrm{pH} 7 \cdot 0$. In each ITC experiment, $3 \mu \mathrm{l}$ aliquots of $0 \cdot 12 \mathrm{mM} \mathrm{BfpB}$ (amino-terminal third) were injected from a $250 \mu \mathrm{l}$ rotating $(280$ r.p.m.) syringe into the $1.4 \mathrm{ml}$ isothermal sample chamber containing $0.003 \mathrm{mM} \mathrm{BfpU}$. Experiments consisted of 35 injections of $6 \mathrm{~s}$ duration at $210 \mathrm{~s}$ intervals. In corresponding control experiments, the amino-terminal third of $\mathrm{BfpB}$ was injected into buffer alone. These heats of dilution of BfpB were subtracted from the heats generated in the titrations with BfpU. Calorimetric data analysis was carried out with ORIGIN 5.0 software (MicroCal). Binding parameters, such as the stoichiometry of binding $(n)$, the binding constant $\left(K_{\mathrm{a}}\right)$ and the binding enthalpy $\left(\Delta H_{\mathrm{a}}\right)$, were determined by fitting the experimental binding isotherm. Three ITC experiments were performed and the mean binding parameters and associated errors were calculated.

\section{RESULTS}

\section{Purification and analysis of BfpG}

The BfpG protein is encoded by the second gene in the $b f p$ operon. We had previously suggested that BfpG might be a lipoprotein, based on a possible signal peptidase II cleavage site before cysteine 14 of the putative pre-protein (Stone et al., 1996). To test this hypothesis, we first cloned the $b f p G$ gene into an expression vector that would allow purification of BfpG on the basis of a carboxyl-terminal His $\mathrm{H}_{6}$ tag. The resulting plasmid, pWS16, was introduced into the $b f p G$ mutant strain UMD928, and transformants were examined after growth in BFP-expressing conditions in the presence of various concentrations of ITPG to induce expression of BfpG-His. We found typical large autoaggregates in cultures grown for $\geqslant 4 \mathrm{~h}$ in the presence of $\geqslant 0.01 \mathrm{mM}$ IPTG. In contrast, no autoaggregates were seen in cultures of the $b f p G$ mutant grown under similar conditions. To quantify the effect, we calculated the AI of the $b f p G$ mutant and the complemented $b f p G$ mutant (Fig. 1A). Compared to the $b f p G$ mutant, both wild-type EPEC E2348/69 and the complemented $b f p G$ mutant UMD928(pWS16) displayed a steady increase in AI. This result indicates that the addition of a carboxyl-terminal $\mathrm{His}_{6}$ tag did not interfere with the function of BfpG. We used PCR to replace with serine the codons for both cysteine 9 and cysteine 14, the latter predicted to be essential for signal peptidase II cleavage and modification of pre-BfpG. The resulting plasmid, pWS52, was identical to pWS16 except for this double mutation and, like pWS16, it was able to complement strain UMD928 for autoaggregation, with increasing AI similar to levels seen when the mutant was complemented with the wild-type gene (Fig. 1A). This result suggests that signal peptidase II cleavage is not required for BfpG function. We confirmed the expression of BfpG by Western blotting, and found that BfpG was expressed only in the presence of IPTG in strains UMD928(pWS16) and UMD928(pWS52) (Fig. 1B). The migration of the $\mathrm{BfpG}-\mathrm{His}$ proteins was slower than that of $\mathrm{BfpG}$, as expected.

We expressed BfpG-His in strain UMD928 and purified the protein by Ni-NTA chromatography. The purified protein migrated on gels as a doublet. The $M_{\mathrm{r}}$ of the slower migrating band was 14700 and that of the faster migrating band was 13800 . Amino-terminal sequencing of the slower band revealed the following amino acids: QESANKNEKLFS. This 
(A)

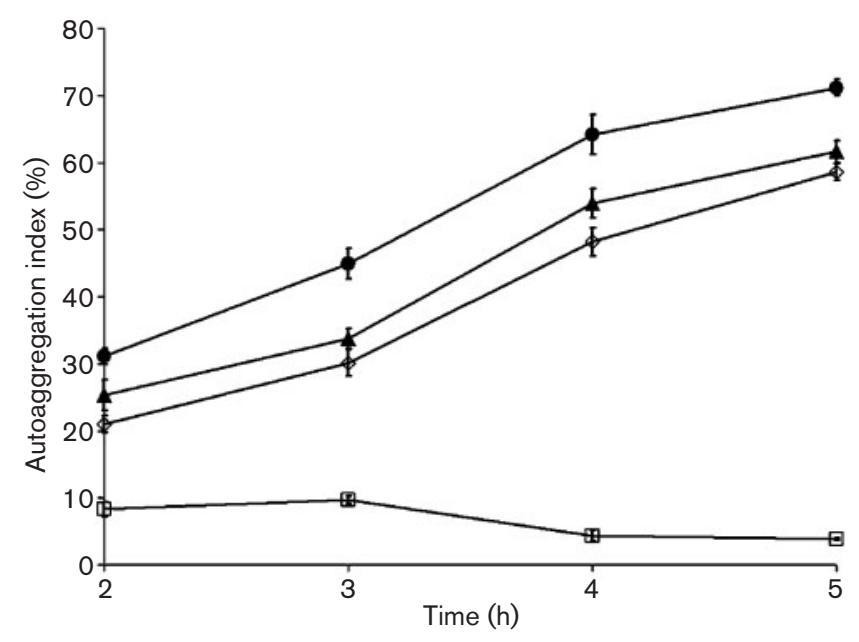

(B)

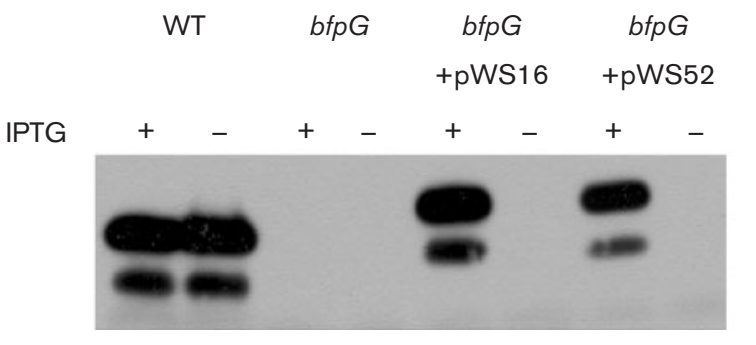

Fig. 1. BfpG cysteine residues 9 and 14 are not required for function. Overnight cultures of wild-type strain E2348/69 (•), bfpG mutant strain UMD928 ( $\square$ ), UMD928 complemented with pWS16 encoding wild-type BfpG (ム), and UMD928 complemented with pWS52 encoding $B^{\prime p} G_{C 9 S} C_{14 S}(\diamond)$, were diluted $1: 250$ in DMEM and incubated at $37^{\circ} \mathrm{C}$. (A) Als were determined on samples at 2, 3, 4 and $5 \mathrm{~h}$. Bars indicate SEM of three independent experiments. (B) Five-hour samples grown in the presence or absence of $0.1 \mathrm{mM}$ IPTG, as indicated, were analysed by immunoblotting with anti-BfpG antibody. WT, wild-type.

sequence is a perfect match for residues 19-30 of BfpG and follows a consensus signal peptidase I cleavage site. The faster migrating band revealed the sequence ALQ(A)SERTI(K)NA, which matches amino acids 37-48, and also follows a consensus signal peptidase I cleavage site. Thus, we conclude that mature BfpG is not a lipoprotein, but rather is processed from pre-BfpG at two alternative sites by signal peptidase I.

\section{Purification of BfpB-Strep}

To aid in the purification of $\mathrm{BfpB}$, we expressed the protein in pWS15, which encodes BfpB-Strep. To ensure that the modified protein was functional, pWS15 was introduced into $b f p B$ mutant strain UMD923 and assayed for autoaggregation. Strain UMD923(pWS15) formed typical large autoaggregates similar to those formed by wild-type EPEC under BFP-inducing conditions in the presence of AHT, while no autoaggregates were seen in the presence of AHT at concentrations $<0.02 \mu \mathrm{g} \mathrm{ml}^{-1}$. We conclude that the addition of a carboxyl-terminal Strep peptide tag does not impair the function of BfpB. BfpB-Strep purified from EPEC, as well as E. coli K-12 backgrounds, was also analysed by electron microscopy (data not shown). We observed ring-shaped structures with outer and inner diameters similar to those previously reported (Schmidt et al., 2001).

\section{BfpB, BfpU and BfpG influence membrane targeting of each other}

Previous studies on localization of various BFP proteins have indicated that $\mathrm{BfpG}$ localizes to the $\mathrm{OM}$ along with BfpB (Ramer et al., 1996; Schmidt et al., 2001), while BfpU localizes to the cytoplasm and periplasm (Schreiber et al., 2002). Since these proteins are present in the OMperiplasm-CM interface, they could potentially interact with one another in the BFP machine and, in turn, influence the localization of each protein to particular cellular compartments. Therefore, we investigated whether the absence of $\mathrm{BfpU}, \mathrm{BfpG}$ or $\mathrm{BfpB}$ proteins altered the localization of each protein. For this analysis, wild-type, mutants and mutant-complemented EPEC strains, as well as laboratory E. coli strains expressing only the BFP protein of interest, were fractionated into insoluble (representing the $\mathrm{OM}$ and $\mathrm{CM}$ proteins) and soluble (representing the cytoplasm and periplasm proteins) fractions. Periplasmic fractions were also prepared separately. Western blotting was conducted on these fractions with specific antibodies. The purity of each fraction was determined by Western blotting with antiGroEL (a cytoplasmic resident protein) and NADH oxidase (a CM protein) assays. The results of the Western blotting are shown in Fig. 2. The distribution of NADH oxidase and GroEL revealed little or no contamination of the insoluble/ soluble fractions. BfpB was detected predominantly in the insoluble fraction of wild-type EPEC strain E2348/69, the $b f p U$ mutant UMD922 and the $b f p G$ mutant UMD928, as well as in the insoluble fraction of laboratory $E$. coli strain XL-1 Blue(pWS15) expressing BfpB-Strep, indicating that targeting of $\mathrm{BfpB}$ to the membrane was independent of BfpU, BfpG, or any other BFP protein (Fig. 2, first panel). $\mathrm{BfpU}$ was present predominantly in the soluble fractions of wild-type EPEC, $b f p G$ mutant UMD928 and the $b f p B$ mutant UMD923 (Fig. 2, second panel). Although less abundant, $\mathrm{BfpU}$ was also detected in the insoluble fractions of wild-type EPEC and the $b f p G$ and $b f p B$ mutants. These results indicate that $\mathrm{BfpU}$ may be present not only in the cytoplasm and periplasm, as previously reported (Schreiber et al., 2002), but might also be associated with the membrane. BfpG was detected in the insoluble and soluble fractions of wild-type EPEC and the $b f p U$ mutant (Fig. 2, third panel). However, in the $b f p B$ mutant, $B f p G$ was detected only in the soluble fraction. In the laboratory E. coli strain RY3080(pWS16) expressing only BfpG-His, BfpG was detected predominantly in the soluble fraction. The small amount of BfpG detected in the insoluble fraction of strain RY3080(pWS16) may have been due to overexpression of 


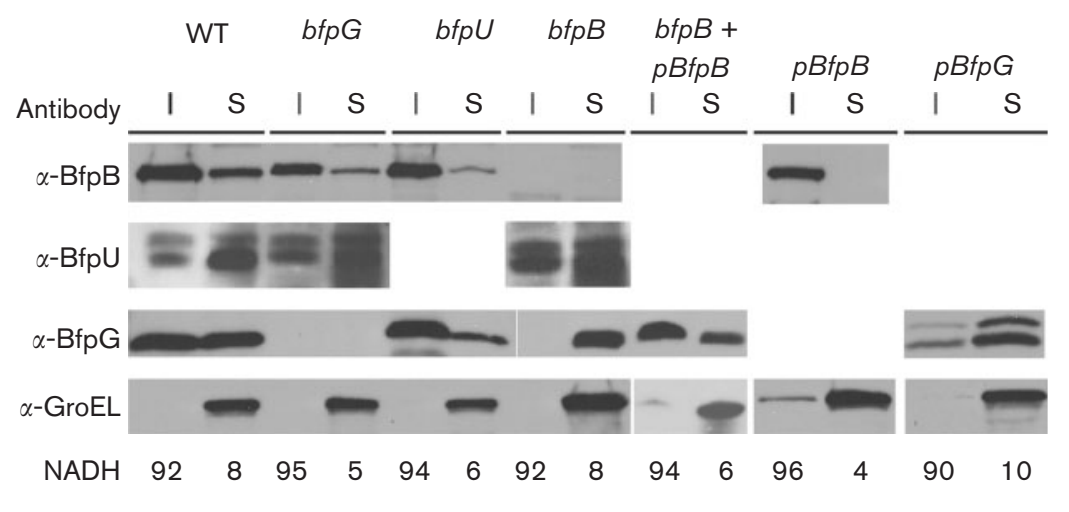

Fig. 2. Influence of $B f p B, B f p U$ and $B f p G$ on membrane targeting of each protein. Cultures of indicated strains were separated into insoluble (I) and soluble (S) fractions as described in Methods. Samples were analysed by Western blotting with the indicated antibodies. Purity of sample preparations was assessed by Western blotting using an antiGroEL antibody and by measuring NADH oxidase activity, shown as a percentage of the total present in each pair of samples. The lanes are labelled as follows: WT, wild-type EPEC strain E2348/69; bfpG, bfpG mutant UMD928; bfpU, bfpU mutant UMD922; $b f p B, b f p B$ mutant UMD923; bfp $B+p B f p B$, $b f p B$ mutant complemented with pWS15; $p B f p B, E$. coli strain XL-1 Blue(pWS15); pBfpG, E. coli strain RY3080(pWS16).

BfpG producing some insoluble protein. These results suggest that targeting of BfpG to the membrane is dependent on the presence of $\mathrm{BfpB}$.

Since localization of BfpG to the membrane appeared to be dependent on the presence of BfpB, and BfpG contained a cleavable signal peptide, we hypothesized that BfpG should have been present in the periplasmic fraction of the $b f p B$ mutant. To test this hypothesis, periplasmic fractions were prepared by treating the cells gently with detergent, followed by Western blotting with anti-BfpG antibodies. BfpG was detected in approximately equal proportions in the periplasmic and cellular pellet fractions of wild-type EPEC (Fig. 3, top panel). However, in the $b f p B$ mutant, BfpG was detected predominantly in the periplasmic fraction. When the $b f p B$ mutant was complemented with a plasmid encoding BfpB-Strep protein, the distribution profile of BfpG was similar to wild-type EPEC, indicating that in the absence of $\mathrm{BfpB}, \mathrm{BfpG}$ localizes primarily in the periplasm.

Western blotting of the periplasmic and cellular pellet fractions of wild-type EPEC with anti-BfpU antibodies detected $\mathrm{BfpU}$ in both fractions, indicating that only a portion of the $\mathrm{BfpU}$ molecules was present in the periplasm. In contrast, in the $b f p B$ mutant, BfpU was detected primarily in the periplasmic fraction, while only a small amount was detected in the cellular pellet fraction. Complementation of the $b f p B$ mutant resulted in an increase in the amount of $\mathrm{BfpU}$ found in the cellular pellet fraction (Fig. 3, second panel). Thus, in the absence of $\mathrm{BfpB}$, there was a redistribution of $\mathrm{BfpU}$ away from the soluble periplasmic fraction. Control experiments with anti-GroEL and anti-MBP antibodies demonstrated the relative purity of the fractions.

\section{BfpB influences membrane targeting of BfpG and BfpU}

Fractionation of cellular components into insoluble/soluble or periplasmic fractions indicated that BfpB, BfpG and BfpU were targeted to the membrane. To determine whether $\mathrm{BfpB}, \mathrm{BfpU}$ or BfpG influence the sorting of each other to the $\mathrm{CM}$ or $\mathrm{OM}$, we subjected various strains to sucrose density flotation gradients and Western blot analysis (Fig. 4). Successive aliquots removed from the top to the bottom of gradients from wild-type EPEC and the $b f p G$ and $b f p U$ mutants, as well as a laboratory E. coli strain expressing BfpB-Strep, were probed with anti-BfpB antibodies, as

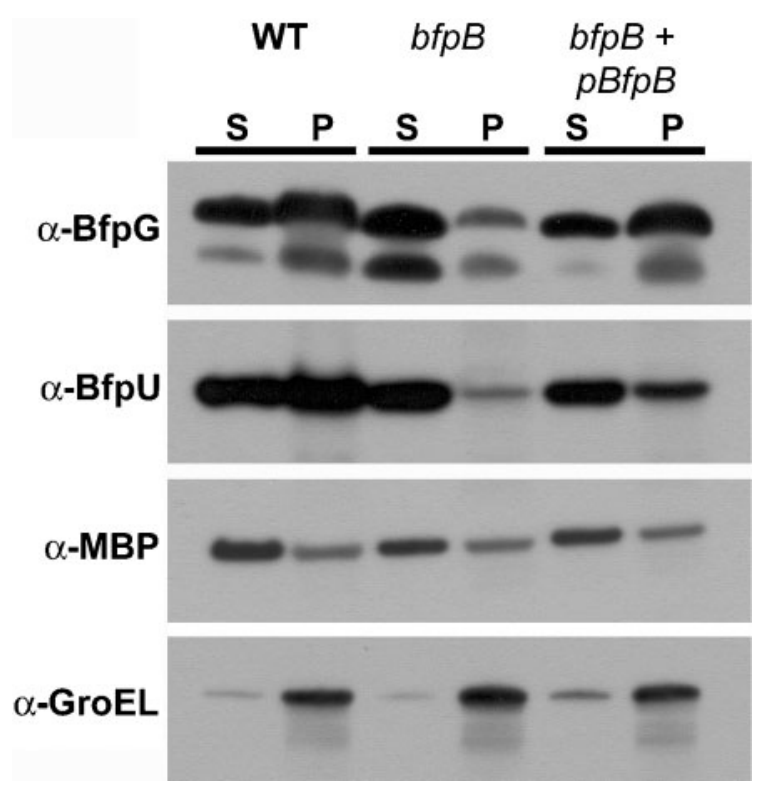

Fig. 3. BfpG is periplasmic in the absence of BfpB. Cultures of wild-type EPEC strain E2348/69 (WT), bfpB mutant UMD923 (bfpB) and complemented bfpB mutant with pWS15 $(b f p B+p B f p B)$ were fractionated into periplasmic supernatant $(S)$ and pellet $(P)$ fractions, as described in Methods. Samples were analysed by Western blotting with indicated antibodies. The purity of sample preparations was assessed by Western blotting using anti-GroEL and anti-MBP antibodies. 
Wild-type

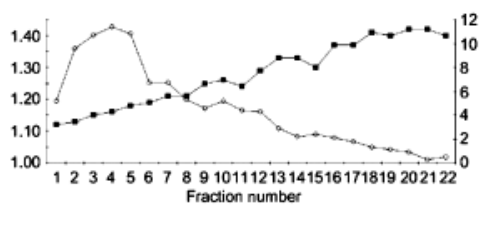

12345678910111213141516171819202122

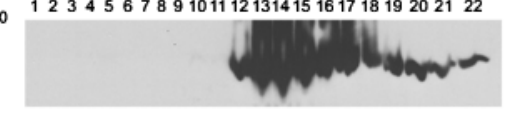

12345678910111213141516171819202122

12345678910111213141516171819202122
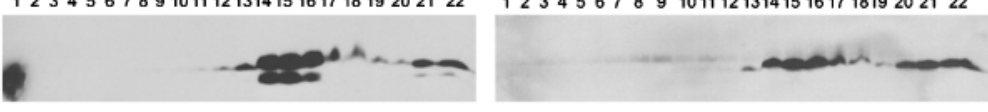

123456789101112131415161718192021

123456789101112131415161718192021

$b f p B$

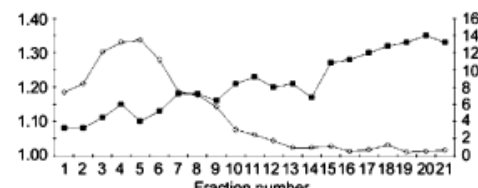
Fraction number

$b f p B+p b f p B$
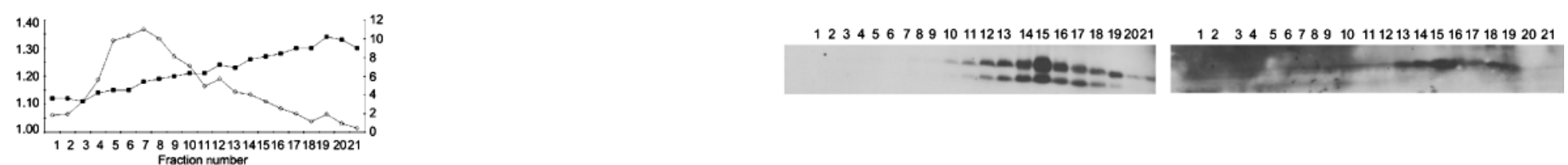

pbfpB

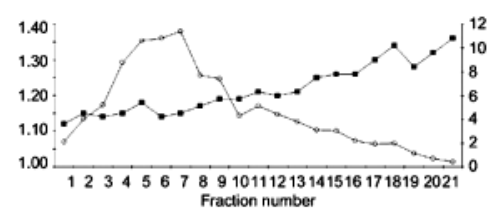

123456789101112131415161718192021

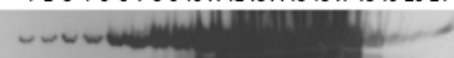

bfpG
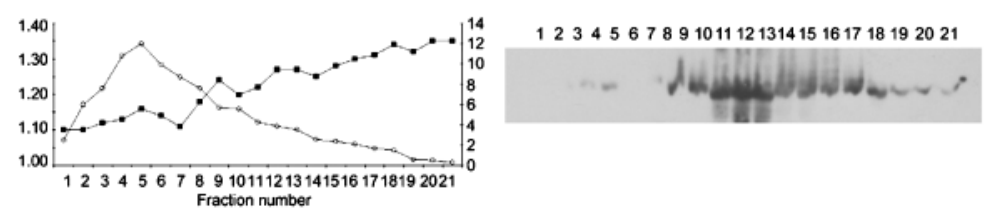

89101112131415
Fraction number

bfpU

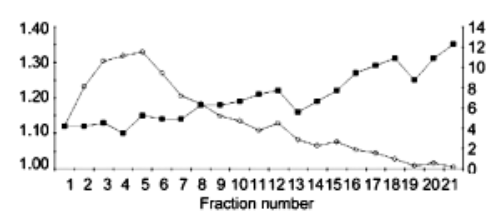

123456789101112131415161718192021

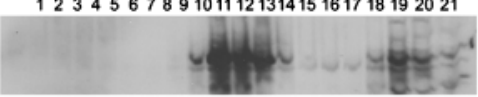

123456789101112131415161718192021

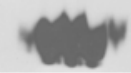

$\alpha-B f p B$

$\alpha-B f p G$

$\alpha-B f p U$

Fig. 4. OM targeting of BfpG is dependent on BfpB. Lysates of the indicated strains were applied to the bottom of 32-60\% sucrose gradients and centrifuged at $288000 \mathrm{~g}$. Aliquots were removed from the top of the gradient, weighed, assayed for NADH activity and analysed by Western blotting. (A) Graphs showing the NADH oxidase activity for each fraction as a percentage of the total NADH oxidase activity (right $y$ axis) and the density of each fraction (left $y$ axis). Western blotting was with anti-BfpB antibodies (B), anti-BfpG antibodies (C) and anti-BfpU antibodies (D). The strains tested are labelled according to Fig. 2. 
shown in Fig. 4(B). BfpB was detected primarily in the fractions corresponding to the $\mathrm{OM}$, as well as in the bottom of the gradient (containing soluble and insoluble proteins) in wild-type EPEC. The distribution of BfpB in the $b f p G$ or $b f p U$ mutant was similar to that of wild-type EPEC. In the E. coli K-12 strain expressing BfpB-Strep alone, the distribution of $\mathrm{BfpB}$ was broader, but peaked in the OM fractions. This result was probably due to overexpression of $\mathrm{BfpB}$ in this strain. These results indicate that $\mathrm{BfpB}$ was targeted to the $\mathrm{OM}$ and the targeting did not depend on the presence of either BfpG or BfpU.

Gradients containing proteins from wild-type EPEC, the $b f p B$ mutant, the complemented $b f p B$ mutant and the $b f p U$ mutant were probed with anti-BfpG antibodies (Fig. $4 \mathrm{C}$ ). $B f p G$ was detected primarily in the fractions corresponding to the OM of wild-type EPEC, similar to BfpB. In the $b f p U$ mutant, BfpG was detected only in the fractions corresponding to the OM. However, in the $b f p B$ mutant, BfpG was detected only in the pellet fraction of the gradient containing soluble (cytoplasm/periplasm) and insoluble proteins. In contrast, in the complemented $b f p B$ mutant, BfpG was present in the OM fractions, similar to wild-type EPEC, in addition to the pellet fraction. These results correlate well with the observations of insoluble/soluble and periplasmic protein separation seen above, and indicate that $\mathrm{BfpB}$ is required for targeting of BfpG to the OM.

The results of probing gradient fractions from wild-type EPEC, the $b f p G$ mutant, the $b f p B$ mutant and the complemented $b f p B$ mutant with anti-BfpU antibodies are shown in Fig. 4(D). BfpU was detected in fractions corresponding to the $\mathrm{OM}$, as well as in the pellet fractions, indicating that $\mathrm{BfpU}$ seen in the insoluble fraction of wildtype EPEC (Fig. 2, second panel) was due to its association with the OM. The distribution of $\mathrm{BfpU}$ in the gradients from the $b f p G$ and $b f p B$ mutants appeared to differ from that in the wild-type EPEC gradient, in that more of the protein could be found in the lighter fractions (Fig. 4D). These results may indicate that $\mathrm{BfpB}$ can influence the membrane localization of BfpU.

\section{Cross-linking and affinity purification of protein complexes}

Based on the results of the fractionation and localization experiments which suggest that $\mathrm{BfpB}$ influences cellular location of $\mathrm{BfpG}$ and may influence the localization of $\mathrm{BfpU}$, we hypothesized that $\mathrm{BfpB}$ functions as a central component of an OM subassembly, and probably interacts not only with $\mathrm{BfpG}$ and $\mathrm{BfpU}$, but also with periplasmic domains of proteins of the BFP machine. Therefore, potential protein interactions at the OM-periplasm interface were investigated to identify these proteins. We conducted chemical cross-linking with DSP, followed by Western blotting to identify components of $\mathrm{BfpB}, \mathrm{BfpU}$ and $\mathrm{BfpG}$ complexes. Cross-linked proteins were purified from $b f p U, b f p G$ and $b f p B$ mutants complemented with plasmids encoding functional BfpU-His, BfpG-His and BfpB-Strep proteins, respectively. The complexes were purified by affinity chromatography and separated by SDS-PAGE in the presence and absence of the reducing agent $\beta$-ME. The gels were either silver-stained (Fig. 5A) or transferred onto PVDF filters and analysed by Western blotting with antibodies against specific Bfp proteins (Fig. 5B).

Silver-stained gels revealed that proteins were present in the eluate fractions, but not in the wash fractions, from all strains except the wild-type EPEC strain E2348/69 (Fig. 5A). Since E2348/69 lacks the affinity tags, this control indicates that the eluted proteins bound specifically to the column with negligible non-specific binding. The elution profile in the $\beta$-ME-containing lanes appeared to be similar for BfpUHis- and BfpG-His-purified complexes, and different for the BfpB-Strep-purified complex (Fig. 5A). These results suggest that the individual components in $\mathrm{BfpU}-\mathrm{His}$ and BfpG-His complexes may be similar, while the BfpB-Strep complex may contain an additional subset of BFP proteins.

To identify the cross-linked proteins in the BfpG, BfpU and $\mathrm{BfpB}$ complexes, Western blot analyses were conducted with available anti-bundlin, anti-BfpB, anti-BfpC, anti-BfpG and anti-BfpU antibodies (Fig. 5B). The BfpG-His complex, when probed with anti-BfpB and anti-BfpU antibodies, revealed bands corresponding to $\mathrm{BfpB}$ and $\mathrm{BfpU}$ in the flowthrough and eluate fractions (Fig. 5B, left panel). However, when the BfpG-His complex was probed with anti-bundlin and anti-BfpC antibodies, the bands corresponding to bundlin and $\mathrm{BfpC}$ were present in the flow-through but not in the eluate fractions (Fig. 5B, left panel). These results suggest the presence of a complex composed of $\mathrm{Bfp} B, \mathrm{BfpU}$ and $\mathrm{BfpG}$ proteins that does not include bundlin or BfpC. Alternatively, there could be separate BfpG-BfpU and BfpG-BfpB complexes, or there could be complexes that include $\mathrm{BfpC}$ and bundlin that we could not detect.

In contrast to the results obtained with the purified BfpGHis complex, a band corresponding to bundlin was present in the $\beta$-ME-containing flow-through and eluate lanes when the BfpU-His complex was probed with anti-bundlin antibodies (Fig. 5B, middle panel). Additionally, a band with an $M_{\mathrm{r}}$ of $\sim 30000$ was present in the non-reduced eluate lane when probed with anti-bundlin antibodies (Fig. 5B, middle panel asterisk). A similar band of $\sim 30 \mathrm{kDa}$ was also seen when the BfpU-His complex was probed with anti-BfpU antibodies (Fig. 5B, middle panel asterisk; note that a band in the reduced lane migrates slightly slower than the indicated band and likely represents a different protein). This band could possibly be a 1:1 complex of bundlin and BfpU, as the relative mobility was similar to that of the sum of those of BfpU and bundlin. When the BfpU-His complex was probed with anti-BfpB and -BfpG antibodies, bands corresponding to $\mathrm{BfpB}$ and $\mathrm{BfpG}$ were present in the flowthrough and eluate fractions (Fig. 5B, middle panel). However, when probed with anti-BfpC antibodies, the corresponding $\mathrm{BfpC}$ band was present in the flow-through but not in the eluate fraction (Fig. 5B, middle panel). These results indicate that $\mathrm{BfpU}$ exists in close proximity to 


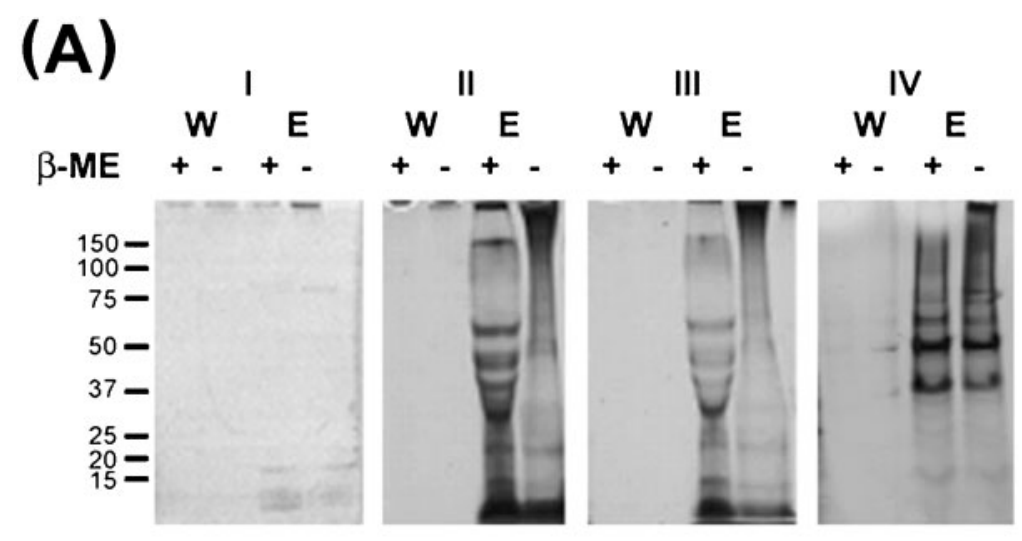

(B)
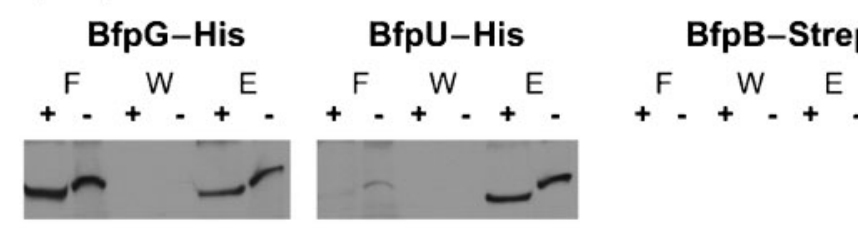

$\beta-M E$

$\alpha-B f p B$
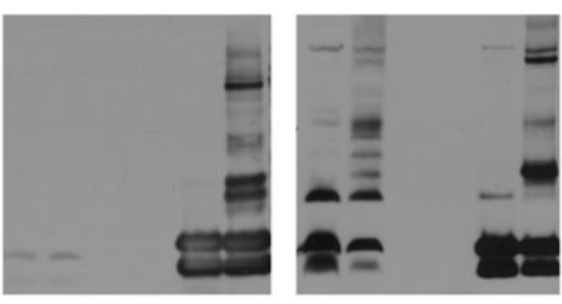

$\alpha-B f p G$
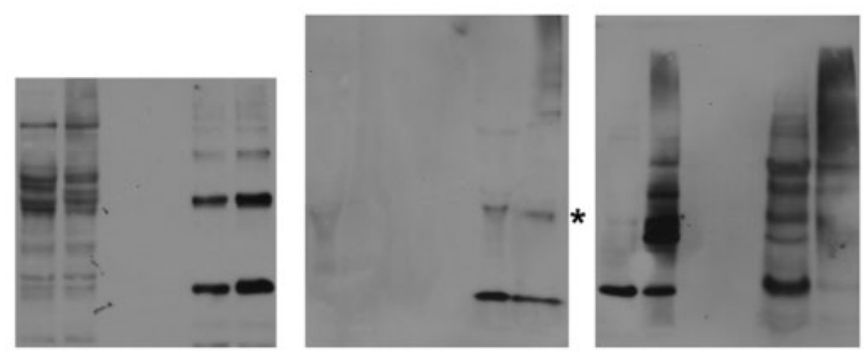

$\alpha-B f p U$
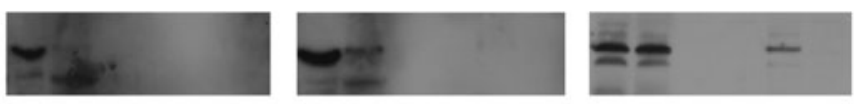

$\alpha-B f p C$
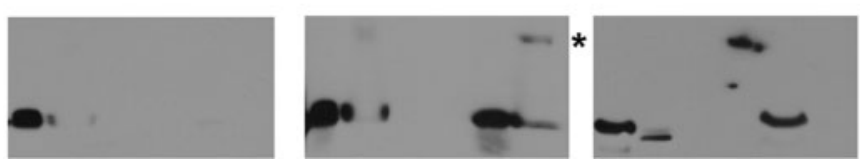

Fig. 5. Silver staining and Western blot analyses of affinity-purified, chemically crosslinked complexes. (A) Silver-stained gels of wash (W) and eluate (E) fractions of chemically cross-linked complexes purified by affinity chromatography from (I) wild-type strain E2348/69, (II) complemented bfpG mutant UMD928(pWS16) expressing BfpGHis, (III) complemented bfpU mutant UMD922(pMSD235) expressing BfpU-His, and (IV) complemented bfpB mutant UMD923(pWS15) expressing BfpB-Strep, separated in the presence $(+)$ or absence $(-)$ of $\beta$-ME. (B) Flow-through (F), wash (W) and eluate (E) samples from chemically crosslinked complexes, affinity-purified by virtue of the tagged proteins indicated at the top of each column, were separated by SDSPAGE in the presence $(+)$ or absence $(-)$ of $\beta-\mathrm{ME}$, transferred to PVDF filters, and analysed with the antibodies indicated on the right. bundlin, BfpB and BfpG. Additionally, BfpU may form separate complexes with bundlin and BfpG/BfpB, since bundlin was not detected when BfpG was tagged (above). This latter possibility is compatible with the $30 \mathrm{kDa}$ bands detected in the cross-linked lane of both anti-bundlin and anti-BfpU blots.

The results of the Western blot analyses of BfpB-Strep complex probed with anti-bundlin, anti-BfpC, anti-BfpU and anti-BfpG antibodies are shown in Fig. 5(B), lower panel.
The bands corresponding to bundlin, BfpC, BfpU and BfpG were present in the flow-through and eluate fractions of the $\mathrm{BfpB}-$ Strep complex, indicating that $\mathrm{BfpB}$ exists in close proximity with all these proteins. The presence of $\mathrm{BfpC}$ in the $\mathrm{BfpB}$ complex is unique to the $\mathrm{BfpB}$ cross-linked proteins, and confirms previously published results (Hwang et al., 2003).

Full analysis of all the proteins potentially present in complexes composed of proteins cross-linked to BfpU, BfpG 
and $\mathrm{BfpB}$ was limited by the availability of specific antibodies against additional Bfp proteins. Therefore, we were unable to confirm the presence of additional proteins (Hwang et al., 2003).

\section{Interactions among OM components BfpG, BfpB and BfpU in yeast}

Since chemical cross-linking experiments revealed that complexes purified by virtue of $\mathrm{BfpB}, \mathrm{BfpG}$ or BfpU each contained the other proteins, we hypothesized that BfpG is not only in close proximity, but interacts directly with BfpB and BfpU. Similarly, BfpU may interact directly with BfpB. To test these hypotheses, a yeast two-hybrid system was used to study the individual interactions of $\mathrm{BfpB}$ with BfpG, BfpB with BfpU, and BfpG with BfpU. BfpB, BfpG and BfpU were fused in-frame with both the GAL4 DNAbinding domain and the GAL4 activation domain. The respective plasmid derivatives were co-transformed into Saccharomyces cerevisiae strain AH109 and screened for expression of three reporter genes his3, ade2 and mell, which are under the control of a GAL4-inducible promoter, and are expressed if the fusion proteins interact. Yeast expressing interacting fusion protein pairs grew as blue colonies on selective media containing $\mathrm{X}-\alpha-\mathrm{Gal}$ and lacking tryptophan, leucine, histidine and adenine $(-4 \mathrm{AA})$. Our results revealed interactions between murine p53 and SV40 large T-antigen (positive control) and between BfpG and BfpB (Fig. 6). The interactions were confirmed by a quantitative $\alpha$-galactosidase
$(\alpha-G a l)$ assay (Fig. 6). However, there was no evidence of interaction between BfpG and BfpU, since the co-transformants, similar to the negative control, were unable to grow on the selective $-4 \mathrm{AA}$ plates. When the $\mathrm{BfpB}$ and $\mathrm{BfpU}$ interaction was tested, there was no growth on the selective $-4 \mathrm{AA}$ plates but intermediate activity was seen in the $\alpha$-Gal assay (Fig. 6). The intermediate $\alpha$-Gal activity, and absence of growth on selective -4AA plates, suggest that the potential interaction between $\mathrm{BfpB}$ and $\mathrm{BfpU}$ in this system might be of low affinity, or transient. Importantly, all colonies of transformants containing individual constructs were white on medium containing $\mathrm{X}-\alpha$-Gal and lacking tryptophan, or containing $\mathrm{X}-\alpha-\mathrm{Gal}$ and lacking leucine, verifying that there was no autoinduction of the reporter genes in the absence of the interacting partners (data not shown). Interactions between $\mathrm{BfpB}$ and $\mathrm{BfpG}$ and many other components of the $\mathrm{BFP}$ biogenesis machine, including $\mathrm{BfpD}, \mathrm{BfpF}$, the cytoplasmic amino terminus and periplasmic carboxyl terminus of BfpC, and the cytoplasmic amino terminus and two periplasmic loops of BfpE, were also investigated. No evidence of an interaction between $\mathrm{BfpB}$ and any of these proteins was detected (data not shown). Thus, the presence of $\mathrm{BfpC}$ in the cross-linked complex purified using BfpB-Strep may not have been due to direct interaction between the two proteins.

BfpB belongs to the secretin family of OM proteins (Ramer et al., 1996). Secretins are predicted to be rich in $\beta$-pleated sheets that are presumed to fold to form transmembrane $\beta$ barrels (Koebnik et al., 2000). Secondary structure analysis

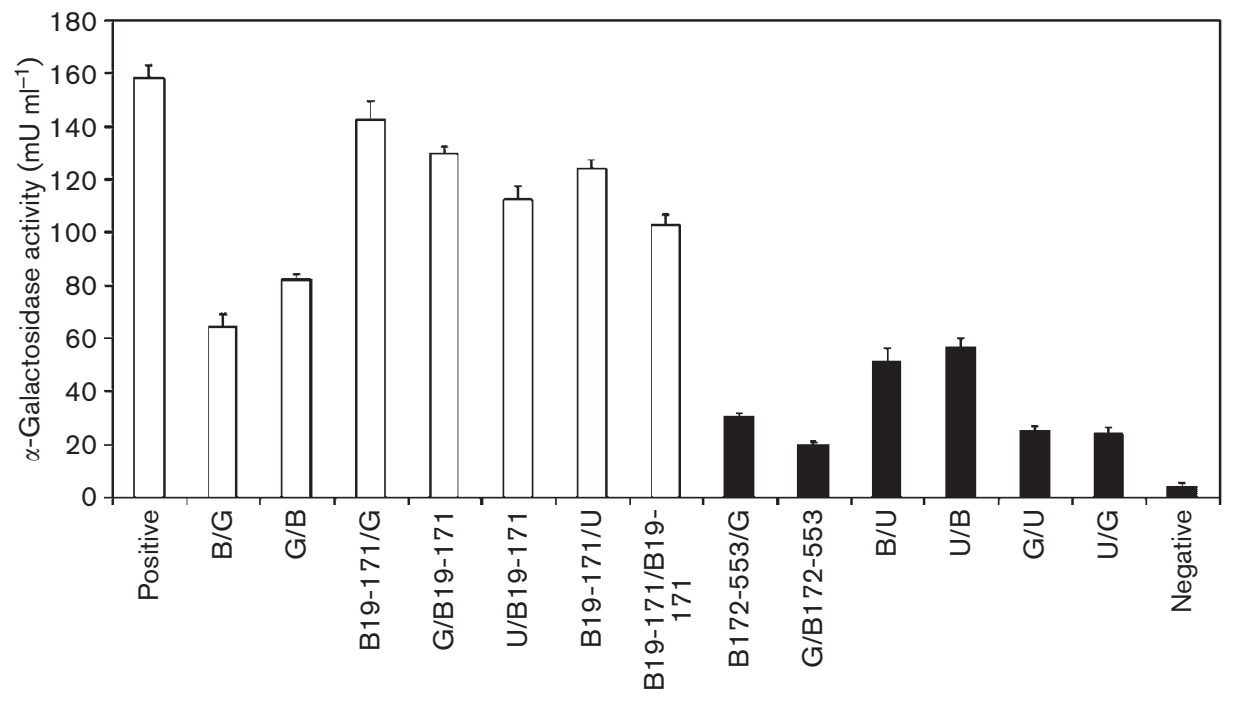

Strain

Fig. 6. Yeast two-hybrid analyses. Construct pairs in vectors pGADT7 and pGBKT7, respectively, were co-transformed into yeast strain AH109 (only the Bfp protein encoded on vectors pGADT7 and pGBKT7, respectively, is indicated). Blue growth on medium containing $\mathrm{X}-\alpha-\mathrm{Gal}$ and lacking histidine and adenine indicated transcriptional activation of reporters, his3, ade2 and me/1. Activation was quantified by measuring $\alpha$-Gal activity. White bars represent transformants that resulted in growth of blue colonies on selective medium, while those that did not are shown as black bars. Columns denote the mean $\pm \operatorname{SEM} \alpha$-Gal activity from three experiments, each performed in triplicate. 
of $\mathrm{BfpB}$ revealed that $\beta$-sheets were present predominantly in the carboxyl-terminal two-thirds of the protein, beginning with residue 172 , while few $\beta$-sheets were predicted in the amino-terminal third of the mature protein. Thus, we hypothesized that $\mathrm{BfpB}_{19-171}$ is not part of this $\beta$-barrel structure, but is present in the periplasmic space and contains possible $\mathrm{BfpG}$ and $\mathrm{BfpU}$ binding sites. We reasoned that folding of the $\mathrm{BfpB}$ structure may have interfered with its translocation to the yeast nucleus, and thus reduced our ability to detect an interaction with BfpU. To determine whether BfpG or BfpU can interact with the amino terminus of $\mathrm{BfpB}$, sequences of $b f p B$ encoding $\mathrm{BfpB}_{19-171}$ and $\mathrm{BfpB}_{172-553}$ were cloned in-frame with both the GAL4 DNA-binding domain and the GAL4 activation domain. These constructs were co-transformed with BfpG and BfpU expression plasmids, and growth was assayed on selective $-4 \mathrm{AA}$ media containing $\alpha$-Gal. Growth of co-transformants on selective $-4 \mathrm{AA}$ plates, as well as the quantitative $\alpha$-Gal assay, revealed that $\mathrm{BfpB}_{19-171}$ interacted with itself and both $\mathrm{BfpG}$ and $\mathrm{BfpU}$, while no interaction between $\mathrm{BfpB}_{172-553}$ and BfpG could be detected (Fig. 6).

\section{Purified BfpU and the amino-terminal third of $\mathrm{BfpB}$ interact in vitro}

We used ITC to characterize the binding of purified and refolded $\mathrm{BfpB}_{19-171}$ to purified $\mathrm{BfpU}$. The ITC profiles resulting from injection of $\mathrm{BfpB}_{19-171}$ into a solution of $\mathrm{BfpU}$ at $37^{\circ} \mathrm{C}$ are shown in Fig. 7. Each of the spikes in the top panel of Fig. 7 corresponds to a single BfpB injection. The areas under these spikes were determined by integration to yield the associated injection heats. These injection heats were corrected by subtraction of the corresponding dilution heats derived from the injection of identical amounts of $\mathrm{BfpB}_{19-171}$ into buffer alone. The bottom panel of Fig. 7 shows the corrected injection heats for the titration of $\mathrm{BfpB}$ into $\mathrm{BfpU}$ plotted as a function of the $\mathrm{Bfp} B / \mathrm{BfpU}$ ratio. In this panel, the data points reflect the corrected experimental injection heats, while the line reflects the calculated fit of the data with a model for one set of binding sites. Consistent with the yeast two-hybrid results, the binding parameters extracted from the binding isotherm show that one molecule of $\mathrm{BfpU}$ and one of $\mathrm{BfpB}_{19-171}$ interact with high affinity $\left(K_{\mathrm{a}}\right.$, $\left.7 \cdot 414 \times 10^{6} \pm 2 \cdot 242 \times 10^{4} \mathrm{M}^{-1} ; n, 0 \cdot 9687 \pm 3 \cdot 36 \times 10^{-3}\right)$, and indicate that complexes in which $\mathrm{BfpU}$ is directly bound to $\mathrm{BfpB}$ are biologically plausible $\left(K_{\mathrm{d}}, 135 \mathrm{nM}\right)$. In addition, the $\Delta H_{\mathrm{a}}$ of $-9 \cdot 232 \times 10^{5} \pm 4 \cdot 542 \times 10^{3} \mathrm{cal} \mathrm{mol}^{-1}$ $\left(3.263 \times 10^{6} \pm 1.900 \times 10^{4} \mathrm{~J} \mathrm{~mol}^{-1}\right)$ shows that the binding of the amino-terminal third of $\mathrm{BfpB}$ to $\mathrm{BfpU}$ is exothermic.

\section{DISCUSSION}

Tfp are homopolymeric filamentous structures expressed as surface appendages by many important pathogenic micro-organisms. Tfp function in diverse processes and are assembled by a multi-component molecular machine. Proteins of the Tfp biogenesis machine share similarity to components of protein secretion and DNA uptake systems.

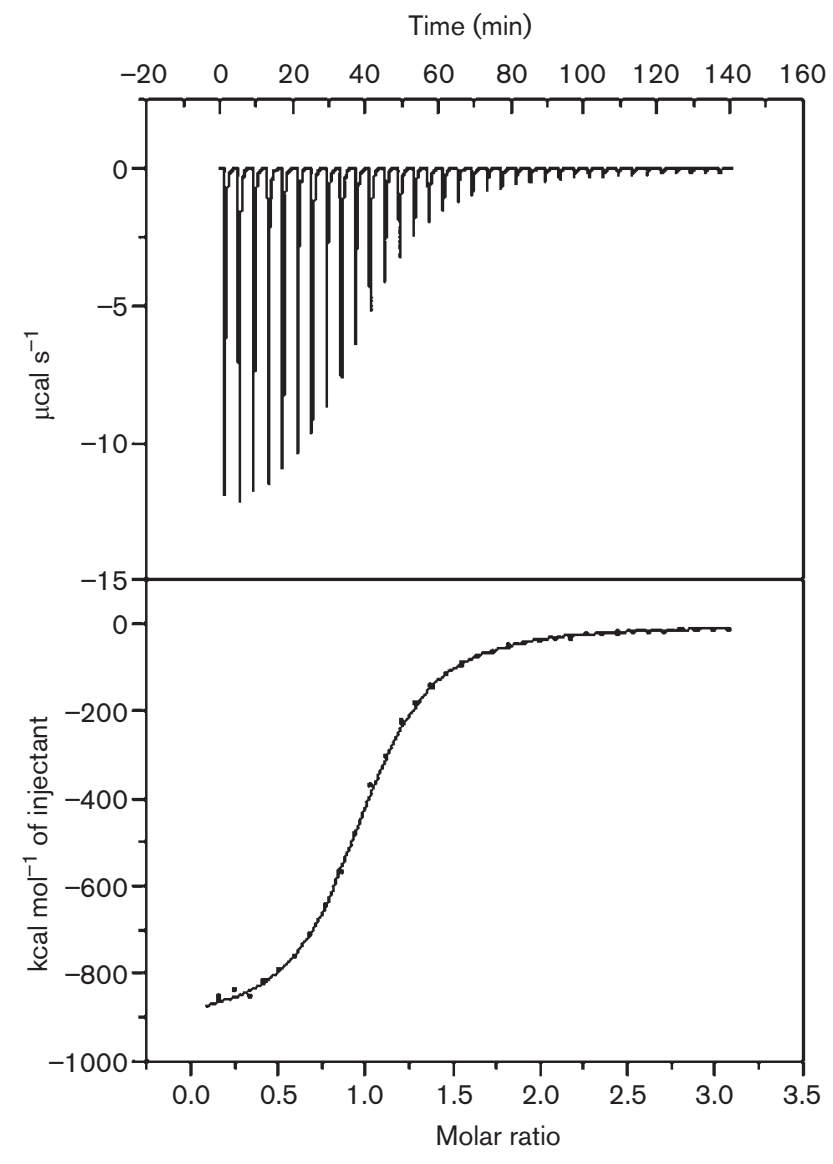

Fig. 7. ITC profiles for the titration of $\mathrm{BfpB}_{19-171}$ into $\mathrm{BfpU}$ at $37^{\circ} \mathrm{C}$. The top panel shows the raw data of calorimetric titration of $0.003 \mathrm{mM} \mathrm{BfpU}$ with $0.12 \mathrm{mM} \mathrm{BfpB}_{19-171}$. The bottom panel shows the integrated heats, after subtraction of the heat of dilution and normalization with the moles of $\mathrm{BfpB}$ injected, plotted as a function of the $\mathrm{BfpB} / \mathrm{BfpU}$ ratio together with the calculated fit of the data with a model for one set of binding sites.

EPEC express one such Tfp called BFP, which is assembled and retracted by proteins encoded by the $b f p$ operon. The BFP system is an excellent model for the study of Tfp, as recombinant bacteria transformed with the $b f p$ genes express pili (Stone et al., 1996). Individual components of the BFP machinery have been identified and some of the components have been extensively characterized (Ramboarina et al., 2005; Crowther et al., 2004, 2005; Blank \& Donnenberg, 2001). However, structural and functional characterization of the complete BFP biogenesis machine remains to be accomplished.

The inner-membrane (IM) subassembly consisting of BfpC, $\mathrm{BfpD}, \mathrm{BfpE}$ and $\mathrm{BfpF}$ has been characterized in some detail (Crowther et al., 2004). In this study, we attempted to characterize the OM subassembly, and included in our studies the secretin $\mathrm{BfpB}$ and two other proteins, BfpG and BfpU, which are present at the OM-periplasm interface. By using 
biochemical, biophysical and genetic techniques, we confirmed previous studies that indicate that $\mathrm{BfpB}$ and $\mathrm{BfpG}$ interact with one another, and that $\mathrm{BfpB}$ can be cross-linked to $\mathrm{BfpG}, \mathrm{BfpU}, \mathrm{BfpC}$ and bundlin (Schmidt et al., 2001; Hwang et al., 2003). In addition, we show, to the best of our knowledge for the first time, that BfpB targets BfpG and possibly influences the localization of $\mathrm{BfpU}$ within the cell. In the absence of $\mathrm{Bfp} B, \mathrm{BfpG}$ is a periplasmic protein, while targeting of BfpU appears to be altered. By using a yeast two-hybrid system, we provide, as far as we are aware, the first evidence that BfpG and BfpU bind directly to BfpB, and furthermore, that these proteins both bind to the amino terminus of BfpB. Finally, we confirm the BfpU-BfpB interaction by showing that purified $\mathrm{BfpU}$ binds with relatively high affinity in vitro to the purified amino terminus of BfpB. Future studies will have to take into account the role of the peptidoglycan in interactions in type IV assembly systems.

BfpG is a small protein encoded by the second ORF of the $b f p$ operon. When the $b f p$ operon was originally described, we noted that the predicted start codon was GTG and we speculated that BfpG might be a lipoprotein, owing to the presence of a critical cysteine after a possible signal peptidase II cleavage site (Stone et al., 1996). However, in this study, we conclusively exclude this possibility by demonstrating that site-directed mutagenesis of this cysteine residue has no effect on BfpG size or function. These data confirm those of Schmidt et al., who were unable to detect incorporation of labelled palmitic acid into BfpG (Schmidt et al., 2001). Furthermore, we show that purified BfpG exists in two forms after cleavage at either of two typical signal peptidase I sites, as determined definitively by amino-terminal amino acid sequencing.

In cross-linking assays, we found that $\mathrm{BfpG}$ was present in $\mathrm{BfpB}$-purified complexes and, reciprocally, $\mathrm{BfpB}$ was present in BfpG-purified complexes, confirming prior observations (Schmidt et al., 2001; Hwang et al., 2003). Additionally, BfpG interacted with full-length BfpB in the yeast twohybrid assay, which provides for the first time, as far as we know, evidence that BfpB and BfpG interact directly with one another, rather than merely being part of the same complex. Further refinement suggests that there is a direct interaction between $\mathrm{BfpG}$ and the amino-terminal one-third domain of BfpB. Schmidt et al. (2001) reported that BfpG is required for the formation and/or stability of $\mathrm{BfpB}$ multimers because, in a $b f p G$ mutant, $\mathrm{BfpB}$ is present predominantly as a monomer. However, we found that formation of $\mathrm{BfpB}$ multimers did not strictly require BfpG, since BfpB ring structures were also observed for purified E. coli K-12 $\mathrm{BfpB}$ in the absence of BfpG (data not shown). However, it remains possible that $\mathrm{BfpG}$ is required for $\mathrm{BfpB}$ multimerization in EPEC, but not in E. coli $\mathrm{K}-12$, owing to the presence or absence of additional proteins that affect this process.

We investigated whether the absence of BfpG alters the membrane localization of $\mathrm{BfpB}$. Previous studies have indicated that small lipoproteins, usually encoded adjacent to their cognate secretins, pilot secretins to the OM (Crago \& Koronakis, 1998; Drake et al., 1997; Hardie et al., 1996; Shevchik et al., 1997). Although BfpG is not a lipoprotein, it is of similar size to these pilotins, and is encoded immediately upstream of $b f p B$. Our membrane purification and sucrose density gradient experiments reveal that $\mathrm{BfpB}$ is targeted to the OM (and CM when overexpressed in an E. coli K-12 background) independent of BfpG, thus confirming earlier results that $\mathrm{BfpG}$ is not a pilotin (Schmidt et al., 2001). We also investigated whether the converse is true, i.e. whether the absence of $\mathrm{BfpB}$ alters the targeting of $\mathrm{BfpG}$ to the OM. Our results indicate that BfpG is a peripheral OM protein that is targeted to that location by BfpB. In the wild-type EPEC strain, BfpG was present in the insoluble membrane fraction, which corresponds to the $\mathrm{OM}$ as determined by sucrose density gradient experiments, while, in the $b f p B$ mutant, BfpG was present exclusively in the soluble fraction corresponding to the periplasm/cytoplasm. In the periplasmic separation assays, BfpG was detected primarily in the periplasmic fraction of the $b f p B$ mutant. This result is consistent with the cleavage of BfpG by signal peptidase I and with the overall hydrophilic nature of the mature protein. Additionally, when the $b f p B$ mutant was complemented with functional BfpB protein, BfpG was restored to fractions corresponding to the $\mathrm{OM}$ in density gradient fractionation. The above results conclusively prove that targeting of BfpG to the OM is dependent on BfpB. Interestingly, other investigators have failed to detect $\mathrm{BfpG}$ in the absence of $\mathrm{BfpB}$, and have thus been unable to determine the effect of BfpB on BfpG localization (Ramer et al., 2002). We speculate that our ability to detect BfpG, and in turn determine the effect of $\mathrm{BfpB}$ on BfpG localization, may be due to the nature of the $b f p B$ mutant used for these studies. The mutant that we used is the result of the disruption of the locus with a non-polar gene cassette (Anantha et al., 2000). We could detect the amino terminus of BfpB in this mutant using an antiserum raised against an aminoterminal peptide (data not shown). It is therefore likely that an intact $\mathrm{BfpB}$ protein is required for $\mathrm{BfpG}$ recruitment to the $\mathrm{OM}$, while fragments of $\mathrm{BfpB}$ are sufficient to maintain BfpG stability.

The relationship between $\mathrm{BfpB}$ and BfpG differs in many respects from other known secretin systems, such as the PulD-PulS of Klebsiella, OutS of Erwinia, InvG of S. enterica serotype Typhimurium, as well as PilQ of N. gonorrhoeae and $P$. aeruginosa, as has been discussed in detail by Schmidt et al. (2001). First, the secretin BfpB is a lipoprotein similar to XpsD from Xanthomonas campestris of the pIV-PulD superfamily of OM secretin proteins (Ramer et al., 1996; Genin \& Boucher, 1994; Yen et al., 2002), while the partner BfpG is not a lipoprotein. However, in other members of the pIV-PulD superfamily, the converse is true. Second, the small lipoprotein plays a role in the targeting/stability of secretins. In the BfpB-BfpG system, BfpG is not required for the targeting/stability of BfpB. However, as far as we are aware, our study demonstrates for the first time that the $\mathrm{BfpB}$ secretin is required to recruit the small interacting 
protein $\mathrm{BfpG}$ to the OM. Since vancomycin sensitivity assays suggest that $\mathrm{BfpB}$ forms an incompletely gated channel, a possible function of $\mathrm{BfpG}$ is to function as the gate of the BfpB channel.

Hwang et al. (2003) demonstrated that BfpB cross-links with at least nine $\mathrm{BFP}$ proteins, including $\mathrm{BfpC}$. $\mathrm{BfpC}$, along with $\mathrm{BfpD}, \mathrm{BfpE}$ and $\mathrm{BfpF}$, constitutes the $\mathrm{CM}$ subassembly (Crowther et al., 2004). The presence of BfpC in BfpB crosslinked complexes led Hwang et al. (2003) to postulate that the BFP machine spans the periplasmic space. In our crosslinking assays, we detected BfpC only in BfpB-purified complexes but not in BfpG- or BfpU-purified complexes, suggesting that these complexes are not identical. These results also support the hypothesis that the BFP machine spans the periplasmic space via a BfpB-BfpC interaction. However, when tested in the yeast two-hybrid assay, we did not observe an interaction between BfpB and BfpC (data not shown). Although the two-hybrid results do not prove that there is no interaction between $\mathrm{BfpB}$ and $\mathrm{BfpC}$, we obtained similar results with BfpG and BfpU (discussed below). Thus, currently, it is not clear how the OM and CM subassemblies of the BFP machine are linked.

The distribution of $\mathrm{BfpU}$ in the cell is more complex than that of any other BFP protein. BfpU is present in the periplasm and cytoplasm (Schreiber et al., 2002), as well as in the CM (Ramer et al., 2002). Our membrane fractionation experiments confirm earlier observations that $\mathrm{BfpU}$ is present in the soluble, as well as the membrane fractions. The periplasmic fractionation experiments demonstrate that part of the BfpU pool is periplasmic. In sucrose density gradient fractions, we found that $\mathrm{BfpU}$ was present in the bottom of the sucrose gradient (which contains soluble and aggregated proteins), as well as in the fractions corresponding to the OM. Additionally, the absence of $\mathrm{BfpB}$ appears to alter the distribution profile of $\mathrm{BfpU}$ compared to wild-type EPEC, while, in the complemented $b f p B$ mutant, the distribution of BfpU appears to be similar to that of wild-type $\mathrm{EPEC}$, indicating that $\mathrm{BfpB}$ may also influence the targeting of BfpU within the cell.

Cross-linking assays revealed that BfpU-purified complexes contain BfpB and BfpG. Similarly, BfpU was detected in both BfpB- and BfpG-purified complexes, suggesting that BfpB, $\mathrm{BfpU}$ and $\mathrm{BfpG}$ are in close proximity to each other. When the interactions were tested in the yeast two-hybrid assay, the strain containing full-length $\mathrm{BfpB}$ and BfpU did not grow on selective plates, but exhibited intermediate $\alpha$-Gal activity, which could have been due to weak or transient interaction between these proteins. However, the aminoterminal one-third domain of $\mathrm{BfpB}$ interacted strongly with $\mathrm{BfpU}$. This result suggests that the carboxyl-terminal twothirds of $\mathrm{BfpB}$ inhibits the interaction with $\mathrm{BfpU}$ in yeast, yielding an intermediate result. Furthermore, using ITC, we confirmed that $\mathrm{BfpU}$ binds directly to the amino-terminal third of BfpB. This interaction was equimolar and strong (dissociation constant $1.35 \times 10^{-7} \mathrm{M}$ ). Although these in vitro studies do not simulate conditions present in the native $\mathrm{OM}$ environment, the relatively low dissociation constant of this interaction is indicative of strong binding, suggesting that the $\mathrm{BfpB}-\mathrm{BfpU}$ complex is likely to be present at concentrations found in the bacterial cell. These results further support the notion that $\mathrm{BfpU}$ is a component of the OM subassembly. In contrast, BfpU and BfpG did not interact in the two-hybrid assay, and we were also unable to detect any binding between purified BfpU and BfpG by ITC (data not shown), suggesting that, even though both BfpG and $\mathrm{BfpU}$ are in close proximity and can be cross-linked, the proteins may not interact with each other directly. Thus, the results of the targeting experiments, as well as those of the interaction studies, indicate that $\mathrm{BfpU}$ is a component of the OM subassembly, but also suggest that BfpU can be found in all other compartments as well, especially in the absence of BfpB.

Another novel observation of the cross-linking assay is that bundlin was detected in BfpU-purified complexes. The results of the cross-linking assay do not prove a direct interaction between $\mathrm{BfpU}$ and bundlin, since additional proteins might serve as intermediaries. Nevertheless, the presence of both bundlin and BfpU in the $\mathrm{CM}$, as well in the OM, and the cross-linking between bundlin and BfpU suggest that $\mathrm{BfpU}$ could play a role in the delivery of bundlin to the OM. The presence of BfpU in multiple compartments of the cell, and the interaction of BfpU with components of the OM assembly, as well as components of the CM subassembly (L. J. Crowther and others, unpublished observations), suggest that BfpU plays a dynamic role in the BFP biogenesis process.

In this study, we investigated the interactions among three BFP proteins and with various components of the BFP machine, in an attempt to gain insight into the roles that these proteins play in the BFP biogenesis process. Our results indicate that $\mathrm{BfpB}, \mathrm{BfpG}$ and $\mathrm{BfpU}$ are a part of the $\mathrm{OM}$ subassembly of the BFP biogenesis machine. BfpB appears to be the central component of the OM subassembly, forming a ring with a central channel through which the pilus fibres likely pass. BfpB also targets BfpG and $\mathrm{BfpU}$ to the OM through direct interactions between these proteins and its amino terminus. The complex distribution pattern, as well as the multiple interactions of BfpU, indicate that it plays a dynamic role in the pilus biogenesis process. Ongoing investigations in our laboratory are aimed at defining this role.

\section{ACKNOWLEDGEMENTS}

We thank Steven Munger for assistance with the isothermal titration calorimeter. This work was supported by a Public Health Service grant (R01 AI-37606).

\section{REFERENCES}

Alberts, B. (1998). The cell as a collection of protein machines: preparing the next generation of molecular biologists. Cell 92, 291-294. 
Alm, R. A. \& Mattick, J. S. (1997). Genes involved in the biogenesis and function of type-4 fimbriae in Pseudomonas aeruginosa. Gene 192, 89-98.

Anantha, R. P., Stone, K. D. \& Donnenberg, M. S. (1998). The role of $\mathrm{BfpF}$, a member of the PilT family of putative nucleotide-binding proteins, in type IV pilus biogenesis and in interactions between enteropathogenic Escherichia coli and host cells. Infect Immun 66, 122-131.

Anantha, R. P., Stone, K. D. \& Donnenberg, M. S. (2000). Effects of $b f p$ mutations on biogenesis of functional enteropathogenic Escherichia coli type IV pili. J Bacteriol 182, 2498-2506.

Baldini, M. M., Kaper, J. B., Levine, M. M., Candy, D. C. \& Moon, H. W. (1983). Plasmid-mediated adhesion in enteropathogenic Escherichia coli. J Pediatr Gastroenterol Nutr 2, 534-538.

Bieber, D., Ramer, S. W., Wu, C. Y., Murray, W. J., Tobe, T., Fernandez, R. \& Schoolnik, G. K. (1998). Type IV pili, transient bacterial aggregates, and virulence of enteropathogenic Escherichia coli. Science 280, 2114-2118.

Blank, T. E. \& Donnenberg, M. S. (2001). Novel topology of BfpE, a cytoplasmic membrane protein required for type IV fimbrial biogenesis in enteropathogenic Escherichia coli. J Bacteriol 183, 4435-4450.

Bradley, D. E. (1980). A function of Pseudomonas aeruginosa PAO polar pili: twitching motility. Can J Microbiol 26, 146-154.

Chen, I. \& Dubnau, D. (2003). DNA transport during transformation. Front Biosci 8, s544-s556.

Crago, A. M. \& Koronakis, V. (1998). Salmonella InvG forms a ringlike multimer that requires the InvH lipoprotein for outer membrane localization. Mol Microbiol 30, 47-56.

Craig, L., Pique, M. E. \& Tainer, J. A. (2004). Type IV pilus structure and bacterial pathogenicity. Nat Rev Microbiol 2, 363-378.

Cravioto, A., Gross, R. J., Scotland, S. M. \& Rowe, B. (1979). An adhesive factor found in strains of Escherichia coli belonging to the traditional infantile enteropathogenic serotypes. Curr Microbiol 3, 95-99.

Crowther, L. J., Anantha, R. P. \& Donnenberg, M. S. (2004). The inner membrane subassembly of the enteropathogenic Escherichia coli bundle-forming pilus machine. Mol Microbiol 52, 67-79.

Crowther, L. J., Yamagata, A., Craig, L., Tainer, J. A. \& Donnenberg, M. S. (2005). The ATPase activity of $\mathrm{BfpD}$ is greatly enhanced by zinc and allosteric interactions with other Bfp proteins. J Biol Chem 280, 24839-24848.

Datsenko, K. A. \& Wanner, B. L. (2000). One-step inactivation of chromosomal genes in Escherichia coli K-12 using PCR products. Proc Natl Acad Sci U S A 97, 6640-6645.

Donnenberg, M. S. \& Kaper, J. B. (1992). Minireview: enteropathogenic Escherichia coli. Infect Immun 60, 3953-3961.

Donnenberg, M. S., Girón, J. A., Nataro, J. P. \& Kaper, J. B. (1992). A plasmid-encoded type IV fimbrial gene of enteropathogenic Escherichia coli associated with localized adherence. Mol Microbiol 6, 3427-3437.

Donnenberg, M. S., Zhang, H.-Z. \& Stone, K. D. (1997). Biogenesis of the bundle-forming pilus of enteropathogenic Escherichia coli: reconstitution of fimbriae in recombinant $E$ - coli and role of DsbA in pilin stability - a review. Gene 192, 33-38.

Drake, S. L., Sandstedt, S. A. \& Koomey, M. (1997). PilP, a pilus biogenesis lipoprotein in Neisseria gonorrhoeae, affects expression of PilQ as a high-molecular-mass multimer. Mol Microbiol 23, 657-668.

Genin, S. \& Boucher, C. A. (1994). A superfamily of proteins involved in different secretion pathways in gram-negative bacteria: modular structure and specificity of the N- terminal domain. Mol Gen Genet 243, 112-118.
Girón, J. A., Ho, A. S. Y. \& Schoolnik, G. K. (1991). An inducible bundle-forming pilus of enteropathogenic Escherichia coli. Science 254, 710-713.

Girón, J. A., Qadri, F., Azim, T., Jarvis, K. J., Kaper, J. B. \& Albert, M. J. (1995). Monoclonal antibodies specific for the bundle-forming pilus of enteropathogenic Escherichia coli. Infect Immun 63, 4949-4952.

Guzman, L. M., Belin, D., Carson, M. J. \& Beckwith, J. (1995). Tight regulation, modulation, and high-level expression by vectors containing the arabinose PBAD promoter. J Bacteriol 177, 4121-4130.

Hardie, K. R., Lory, S. \& Pugsley, A. P. (1996). Insertion of an outer membrane protein in Escherichia coli requires a chaperone-like protein. EMBO J 15, 978-988.

Henrichsen, J. (1983). Twitching motility. Annu Rev Microbiol 37, 81-93.

Herrington, D. A., Hall, R. H., Losonsky, G., Mekalanos, J. J., Taylor, R. K. \& Levine, M. M. (1988). Toxin, toxin-coregulated pili, and the toxR regulon are essential for Vibrio cholerae pathogenesis in humans. J Exp Med 168, 1487-1492.

Hobbs, M. \& Mattick, J. S. (1993). Common components in the assembly of type 4 fimbriae, DNA transfer systems, filamentous phage and protein-secretion apparatus: a general system for the formation of surface-associated protein complexes. Mol Microbiol 10, 233-243.

Hottenrott, S., Schumann, T., Pluckthun, A., Fischer, G. \& Rahfeld, J. U. (1997). The Escherichia coli SlyD is a metal ion-regulated peptidyl-prolyl cis/trans-isomerase. J Biol Chem 272, 15697-15701.

Hwang, J., Bieber, D., Ramer, S. W., Wu, C. Y. \& Schoolnik, G. K. (2003). Structural and topographical studies of the type IV bundleforming pilus assembly complex of enteropathogenic Escherichia coli. J Bacteriol 185, 6695-6701.

Koebnik, R., Locher, K. P. \& Van Gelder, P. (2000). Structure and function of bacterial outer membrane proteins: barrels in a nutshell. Mol Microbiol 37, 239-253.

Lee, K. K., Sheth, H. B., Wong, W. Y., Sherburne, R., Paranchych, W., Hodges, R. S., Lingwood, C. A., Krivan, H. \& Irvin, R. T. (1994). The binding of Pseudomonas aeruginosa pili to glycosphingolipids is a tip-associated event involving the $C$-terminal region of the structural pilin subunit. Mol Microbiol 11, 705-713.

Levine, M. M., Bergquist, E. J., Nalin, D. R., Waterman, D. H., Hornick, R. B., Young, C. R., Sotman, S. \& Rowe, B. (1978). Escherichia coli strains that cause diarrhoea but do not produce heat-labile or heat-stable enterotoxins and are non-invasive. Lancet 1, 1119-1122.

McNamara, B. P., Koutsouris, A., O'Connell, C. B., Nougayrède, J. P., Donnenberg, M. S. \& Hecht, G. (2001). Translocated EspF protein from enteropathogenic Escherichia coli disrupts host intestinal barrier function. J Clin Invest 107, 621-629.

Merz, A. J., So, M. \& Sheetz, M. P. (2000). Pilus retraction powers bacterial twitching motility. Nature 407, 98-102.

O'Connell, C. B., Creasey, E. A., Knutton, S. \& 7 other authors (2004). SepL, a protein required for enteropathogenic Escherichia coli type III translocation, interacts with secretion component SepD. Mol Microbiol 52, 1613-1625.

Osborn, M. J., Gander, J. E., Parisi, E. \& Carson, J. (1972). Mechanism of assembly of the outer membrane of Salmonella typhimurium. Isolation and characterization of cytoplasmic and outer membrane. J Biol Chem 247, 3962-3972.

O'Toole, G. A. \& Kolter, R. (1998). Flagellar and twitching motility are necessary for Pseudomonas aeruginosa biofilm development. Mol Microbiol 30, 295-304.

Peabody, C. R., Chung, Y. J., Yen, M. R., Vidal-Ingigliardi, D., Pugsley, A. P. \& Saier, M. H., Jr (2003). Type II protein secretion and 
its relationship to bacterial type IV pili and archaeal flagella. Microbiology 149, 3051-3072.

Phizicky, E., Bastiaens, P. I., Zhu, H., Snyder, M. \& Fields, S. (2003). Protein analysis on a proteomic scale. Nature 422, 208-215.

Ramboarina, S., Fernandes, P. J., Daniell, S., Islam, S., Simpson, P., Frankel, G., Booy, F., Donnenberg, M. S. \& Matthews, S. (2005). Structure of the bundle-forming pilus from enteropathogenic Escherichia coli. J Biol Chem 280, 40252-40260.

Ramer, S. W., Bieber, D. \& Schoolnik, G. K. (1996). BfpB, an outer membrane lipoprotein required for the biogenesis of bundle-forming pili in enteropathogenic Escherichia coli. J Bacteriol 178, 6555-6563.

Ramer, S. W., Schoolnik, G. K., Wu, C. Y., Hwang, J., Schmidt, S. A. \& Bieber, D. (2002). The type IV pilus assembly complex: biogenic interactions among the bundle-forming pilus proteins of enteropathogenic Escherichia coli. J Bacteriol 184, 3457-3465.

Roof, W. D., Fang, H. Q., Young, K. D., Sun, J. \& Young, R. (1997). Mutational analysis of $s l y D$, an Escherichia coli gene encoding a protein of the FKBP immunophilin family. Mol Microbiol 25, 1031-1046.

Rudel, T., Scheuerpflug, I. \& Meyer, T. F. (1995). Neisseria PilC protein identified as type-4 pilus tip- located adhesin. Nature 373, 357-359.

Russel, M. (1998). Macromolecular assembly and secretion across the bacterial cell envelope: type II protein secretion systems. J Mol Biol 279, 485-499.

Sandkvist, M. (2001). Biology of type II secretion. Mol Microbiol 40, 271-283.

Scaletsky, I. C. A., Silva, M. L. M. \& Trabulsi, L. R. (1984). Distinctive patterns of adherence of enteropathogenic Escherichia coli to HeLa cells. Infect Immun 45, 534-536.

Schmidt, S. A., Bieber, D., Ramer, S. W., Hwang, J., Wu, C. Y. \& Schoolnik, G. (2001). Structure-function analysis of BfpB, a secretinlike protein encoded by the bundle-forming-pilus operon of enteropathogenic Escherichia coli. J Bacteriol 183, 4848-4859.

Schreiber, W., Stone, K. D., Strong, M. A., DeTolla, L. J., Jr, Hoppert, M. \& Donnenberg, M. S. (2002). BfpU, a soluble protein essential for type IV pilus biogenesis in enteropathogenic Escherichia coli. Microbiology 148, 2507-2518.

Seifert, H. S., Ajioka, R. S., Marchal, C., Sparling, P. F. \& So, M. (1988). DNA transformation leads to pilin antigenic variation in Neisseria gonorrhoeae. Nature 336, 392-395.

Shevchik, V. E., Robert-Baudouy, J. \& Condemine, G. (1997). Specific interaction between OutD, an Erwinia chrysanthemi outer membrane protein of the general secretory pathway, and secreted proteins. EMBO J 16, 3007-3016.

Sohel, I., Puente, J. L., Murray, W. J., Vuopio-Varkila, J. \& Schoolnik, G. K. (1993). Cloning and characterization of the bundle-forming pilin gene of enteropathogenic Escherichia coli and its distribution in Salmonella serotypes. Mol Microbiol 7, 563-575.

Stone, B. J. \& Abu Kwaik, Y. (1998). Expression of multiple pili by Legionella pneumophila: identification and characterization of a type
IV pilin gene and its role in adherence to mammalian and protozoan cells. Infect Immun 66, 1768-1775.

Stone, K. D., Zhang, H.-Z., Carlson, L. K. \& Donnenberg, M. S. (1996). A cluster of fourteen genes from enteropathogenic Escherichia coli is sufficient for biogenesis of a type IV pilus. Mol Microbiol 20, 325-337.

Strom, M. S. \& Lory, S. (1993). Structure-function and biogenesis of the type IV pili. Annu Rev Microbiol 47, 565-596.

Strom, M. S., Nunn, D. N. \& Lory, S. (1993). A single bifunctional enzyme, PilD, catalyzes cleavage and $\mathrm{N}$-methylation of proteins belonging to the type IV pilin family. Proc Natl Acad Sci U S A 90, 2404-2408.

Tacket, C. O., Taylor, R. K., Losonsky, G., Lim, Y., Nataro, J. P., Kaper, J. B. \& Levine, M. M. (1998). Investigation of the roles of toxin-coregulated pili and mannose-sensitive hemagglutinin pili in the pathogenesis of Vibrio cholerae O139 infection. Infect Immun 66, 692-695.

Taniguchi, T., Fujino, Y., Yamamoto, K., Miwatani, T. \& Honda, T. (1995). Sequencing of the gene encoding the major pilin of pilus colonization factor antigen III (CFA/III) of human enterotoxigenic Escherichia coli and evidence that CFA/III is related to type IV pili. Infect Immun 63, 724-728.

Vuopio-Varkila, J. \& Schoolnik, G. K. (1991). Localized adherence by enteropathogenic Escherichia coli is an inducible phenotype associated with the expression of new outer membrane proteins. J Exp Med 174, 1167-1177.

Wall, D. \& Kaiser, D. (1999). Type IV pili and cell motility. Mol Microbiol 32, 1-10.

Wolfgang, M., Lauer, P., Park, H. S., Brossay, L., Hébert, J. \& Koomey, M. (1998). PilT mutations lead to simultaneous defects in competence for natural transformation and twitching motility in piliated Neisseria gonorrhoeae. Mol Microbiol 29, 321-330.

Wolfgang, M., van Putten, J. P., Hayes, S. F., Dorward, D. \& Koomey, M. (2000). Components and dynamics of fiber formation define a ubiquitous biogenesis pathway for bacterial pili. EMBO J 19, 6408-6418.

Yen, M. R., Peabody, C. R., Partovi, S. M., Zhai, Y., Tseng, Y. H. \& Saier, M. H. (2002). Protein-translocating outer membrane porins of Gram-negative bacteria. Biochim Biophys Acta 1562, 6-31.

Yoshida, T., Kim, S. R. \& Komano, T. (1999). Twelve pil genes are required for biogenesis of the R64 thin pilus. J Bacteriol 181, 20382043.

Zhang, H.-Z. \& Donnenberg, M. S. (1996). DsbA is required for stability of the type IV pilin of enteropathogenic Escherichia coli. Mol Microbiol 21, 787-797.

Zhang, H.-Z., Lory, S. \& Donnenberg, M. S. (1994). A plasmidencoded prepilin peptidase gene from enteropathogenic Escherichia coli. J Bacteriol 176, 6885-6891.

Zhang, X. L., Tsui, I. S., Yip, C. M., Fung, A. W., Wong, D. K., Dai, X., Yang, Y., Hackett, J. \& Morris, C. (2000). Salmonella enterica serovar Typhi uses type IVB pili to enter human intestinal epithelial cells. Infect Immun 68, 3067-3073. 